\title{
EVALUASI PENGADILAN TINDAK PIDANA KORUPSI DI INDONESIA \\ (STUDI ATAS KEBUTUHAN, PERAN DAN KUALITAS PUTUSAN HAKIM DI PENGADILAN TINDAK PIDANA KORUPSI JAKARTA DAN BANDUNG PASCA PEMBERLAKUAN UNDANG-UNDANG NO. 46 TAHUN 2009 TENTANG PENGADILAN TINDAK PIDANA KORUPSI)
}

\author{
Hasril Hertanto ${ }^{1}$
}

\begin{abstract}
Act No. 46 of 2009 on the Corruption Court established as one of the institutions that play a role in the eradication of corruption. However, in practice can not be separated from the internal and external problems as fruit eradicate corruption demands a very strong community. Recruitment system of judges, the integrity of judges, the quality of the judge's verdict, facilities and infrastructure, and organizational corruption court is an internal problem in the spotlight of society. Corruption tribunal in all districts/cities have extended the court problem load. The quality and quantity of ad hoc judges who examined the case is a separate issue which is currently of concern to the public. This study will try to assess the needs and judge the quality of court corruption. Results of this research is expected to provide inputs to solve the problems concerning the performance of the court Crime.
\end{abstract}

Keywords: special court, judge ad hoc, corruption, law, corruption eradication commission

\begin{abstract}
Abstrak
Undang-undang No. 46 tahun 2009 tentang Pengadilan Tindak Pidana Korupsi yang dibentuk sebagai salah satu lembaga yang berperan dalam pemberantasan tindak pidana korupsi. Namun dalam pelaksanaannya tidak lepas dari permasalahan internal dan eksternal sebagai buah tuntutan pemberantasan tindak pidana korupsi yang sangat kuat dari masyarakat. Sistem rekrutmen hakim, integritas hakim, kualitas putusan hakim, sarana dan prasarana, dan organisasi pengadilan tindak pidana korupsi merupakan permasalahan internal yang tengah menjadi sorotan masyarakat. Pembentukan pengadilan tindak pidana korupsi di seluruh wilayah kabupaten/ kota telah menambah beban permasalahan pengadilan tersebut. Kualitas dan kuantitas hakim ad hoc yang memeriksa perkara merupakan persoalan tersendiri yang saat ini tengah menjadi perhatian masyarakat. Penelitian ini akan mencoba melakukan penilaian atas kebutuhan dan kualitas hakim

\footnotetext{
1 Penulis adalah Staf Pengajar FHUI dan Ketua Masyarakat Pemantau peradilan Indonesia (MaPPI) FHUI. Alamat korespondensi: hasril.h@ui.ac.id.
} 
pengadilan tindak pidana korupsi. Hasil dari riset ini diharapkan dapat memberikan masukan untuk menyelesaikan permasalahan perihal kinerja pengadilan Tindak Pidana.

Kata kunci: pengadilan khusus, hakim ad hoc, korupsi, hukum, komisi pemberantasan tindak pidana korupsi

\section{Pendahuluan}

\section{Latar Belakang}

Hadirnya Komisi Pemberantasan Korupsi (KPK) dan Pengadilan Tindak Pidana Korupsi membuktikan bahwa korupsi bukan sekedar tindak pidana yang biasa. Modus dan pembuktiannya kompleks. Pelakunya pun adalah orang-orang yang menjadi aktor kekuasaan (politis oligarkis) dan juga para pengusaha. Penjelasan umum Undang-undang No 30 tahun 2002 tentang Komisi Pemberantasan Korupsi bahkan secara eksplisit menjelaskan bahwa:

Tindak pidana korupsi tidak lagi dapat digolongkan sebagai kejahatan biasa melainkan telah menjadi suatu kejahatan luar biasa. Begitu pun dalam upaya pemberantasannya tidak lagi dapat dilakukan secara biasa, tetapi dituntut cara-cara yang luar biasa. $^{2}$

Angin segar pemberantasan korupsi berhembus pasca hadirnya KPK dan Pengadilan tindak pidana Korupsi. Keberadaan Pengadilan Tindak Pidana Korupsi tentunya tidak terlepas dari berbagai tantangan. Masa awal berdirinya pengadilan tindak pidana korupsi dapat dikatakan sebagai sebuah harapan baru dalam upaya pemberantasan tindak pidana korupsi sebagaimana diamanatkan oleh UU No 30 Tahun 2002 tentang Komisi Pemberantasan Tindak Pidana Korupsi. Ketentuan Pasal 53 menyatakan bahwa:

Dengan Undang-Undang ini dibentuk Pengadilan Tindak Pidana Korupsi yang bertugas dan berwenang memeriksa dan memutus tindak pidana korupsi yang penuntutannya diajukan oleh Komisi Pemberantasan Korupsi.

Harapan tersebut tetap ada sampai keluarnya putusan Mahkamah Konstitusi Nomor 012-016-019/PUU-IV/2006 yang membuka babak baru yaitu masa transisi Pengadilan Tindak Pidana Korupsi.

Masa transisi pengadilan tindak pidana korupsi terjadi ketika Mahkamah Konstitusi (MK) mengabulkan perkara permohonan

\footnotetext{
${ }^{2}$ Penjelasan Umum Undang-Undang No 30 tahun 2002 tentang Komisi Pemberantasan Tindak Pidana Korupsi.
} 
pengujian UU KPK No 30 tahun 2002 yang menyatakan bahwa Pasal 53 UU KPK yang mengatur tentang Pengadilan Tindak Pidana Korupsi bertentangan dengan Undang-Undang Dasar 1945. Putusan MK memerintahkan agar pengadilan tindak pidana korupsi diatur dengan undang-undang tersendiri yang terpisah dari UU No. 30 Tahun 2002. Namun demikian MK menyatakan bahwa ketentuan Pasal 53 masih mempunyai kekuatan hukum yang mengikat sampai diadakan perubahan paling lambat 3 (tiga) tahun sejak putusan diucapkan. ${ }^{3}$ Batas waktu tiga tahun tersebut ditujukan bagi proses penyusunan undang-undang baru yang dilakukan oleh pemerintah dan DPR.

Masa transisi selama tiga tahun tersebut berakhir ketika pemerintah dan DPR mengesahkan undang-undang tentang pengadilan tindak pidana korupsi yang diatur di dalam UU No.46 Tahun 2009. Masa ini dapat dikatakan sebagai masa penguatan pengadilan tindak pidana korupsi. Sepintas lalu keberadaan undang-undang tersebut nampaknya membawa angin segar dalam upaya pemberantasan tindak pidana korupsi. Namun apabila dicermati lebih lanjut sejumlah ketentuan di dalam undangundang tersebut menyiman "bom waktu" yang dapat menghambat upaya pemberantasan tindak pidana korupsi. Salah satu ketentuan tersebut adalah Pasal 3 yang menyatakan bahwa: Pengadilan Tindak Pidana Korupsi berkedudukan di setiap ibukota kabupaten/kota yang daerah hukumnya meliputi daerah hukum pengadilan negeri yang bersangkutan. Dengan demikian Pengadilan Tindak Pidana Korupsi akan dibentuk di semua daerah dan tidak lagi terpusat di Jakarta.

Pasca pemberlakuan UU No. 46 tahun 2009 tentang Pengadilan Tindak Pidana Korupsi, permasalahan terkait dengan praktik pengadilan tindak pidana korupsi mulai timbul. Persoalan pembentukan pengadilan tindak pidana korupsi di daerah mulai timbul, antara lain perihal anggaran, sarana prasarana, hingga kualitas putusan hakim. ${ }^{4}$ Putusan hakim pengadilan tindak pidana korupsi di sejumlah daerah banyak membebaskan para terdakwa pelaku tindak pidana korupsi yang tentunya telah mengejutkan publik dan menjadi perhatian sejumlah kalangan,

\footnotetext{
${ }^{3}$ Mahkamah Konstitusi, Putusan Mahkamah Konstitusi No. 012-016-019/PUU-IV/2006. hal. 290 .

4 Dalam Laporan tahunan Mahkamah Agung RI disebutkan bahwa persoalan pembentukan pengadilan tipikor salah satunya terkendala oleh ketersediaan Anggaran. Amanah pasal 35 ayat (1) Undang_undang No 46 tahun 2009 tentang Pengadilan Tindak Pidana Korupsi mengharuskan pembentukan pengadilan tindak pidana korupsi di setiap ibu kota provinsi. Tahun 2010 secara bertahap MA telah merencanakan membentuk 17 pengadilan tipikor di daerah. Namun MA sendiri mengalami keterbatasan anggaran lantaran anggaran MA telah teralokasi secara efektif untuk satuan kerja prioritas yang lainnya. Untuk mengatasi hal itu MA juga telah memintakan tambahan anggaran melalui APBN-P tahun 2010, namun tambahan anggaran juga tak kunjung dikucurkan. Sebagaimana dikutip dari Mahkamah Agung RI, “Laporan Tahunan 2010”, hal. 345.
} 
termasuk penggiat anti korupsi. ${ }^{5}$ Putusan bebas bagi para terdakwa tindak pidana korupsi hampir tidak pernah terjadi ketika pengadilan tindak pidana korupsi masih ditangani di Pengadilan Tindak Pidana Korupsi di Jakarta. Para pengamat dan ahli hukum pun banyak memberikan pendapat yang mengkritik putusan-putusan tersebut. ${ }^{6}$ Beberapa saran yang diajukan antara lain, menyarankan agar pengadilan tindak pidana korupsi dikembalikan ke pusat, ${ }^{7}$ membekukan pengadilan tindak pidana korupsi didaerah untuk sementara agar dapat dievaluasi, ${ }^{8}$ Bahkan ada juga pejabat publik yang memberikan saran ektrim untuk membubarkan pengadilan tindak pidana korupsi di daerah karena gagal mengadili pelaku tindak pidana korupsi sebagaimana mestinya. ${ }^{9}$

Berdasarkan persoalan tersebut, penelitian ini mencoba untuk memunculkan beberapa dugaan awal atas persoalan tersebut. Asumsi yang diajukan dalam penelitian ini adalah bahwa rezim Undang-Undang No 46 tahun 2009 tentang Pengadilan Tindak Pidana Korupsi memunculkan persoalan baru yang melemahkan upaya pemberantasan tindak pidana korupsi. Sejumlah persoalan yang muncul pasca disahkannya UU Pengadilan Tindak Pidana Korupsi (tipikor), antara lain terkait dengan persoalan infrastruktur sarana dan prasarana. Mahkamah Agung sendiri mengakui dalam laporan tahunan tahun 2010 bahwa pembentukan pengadilan Tipikor daerah di 33 provinsi membutuhkan biaya yang cukup besar. Dengan alasan tersebut, penelitian secara khusus

5 Data pantauan ICW tercatat 50 terdakwa kasus korupsi yang dibebaskan oleh pengadilan Tipikor daerah vonis bebas tersebut tersebar di Pengadilan Tipikor Surabaya(25 vonis bebas), Tipikor Makassar (4 vonis), Tipikor Bandung (4), Tipikor Samarinda (15 vonis), Tipikor Semarang dua vonis bebas dan di Tipikor Palembang terdapat satu putusan bebas terhadap terdakwa korupsi. Lihat Pengadilan Tipikor Daerah Vonis Bebas 50 Koruptor, $<$ http://news.okezone.com/read/2012/03/04/339/586884/pengadilan-tipikor-daerah-vonisbebas-50-koruptor>, diakses 16 Juli 2012.

${ }^{6}$ Pendapat Pakar Hukum Tata Negara sekaligus mantan ketua Mahkamah Konstitusi Jimly Asshiddiqie misalnya, beliau tak setuju pengadilan tipikor dibubarkan. Menurutnya yang sebaiknya dilakukan adalah evaluasi terhadap pengadilan tipikor daerah baik dari sisi manajemen mapun hakim-hakim ad hoc nya. Pendapat ini berbeda dari Mahfud Md yang juga pakar hukum tatanegara sekaligus ketua Mahkamah Konstitusi aktif yang sebelumnya melontarkan pendapat agar sebaiknya membubarkan pengadilan Tipikor daerah. Lihat Jimly: Pengadilan Tipikor Daerah Tak Perlu Dibubarkan, <http://nasional.kompas.com/read/2011/ 11/05/12553580/Jimly.Pengadilan.Tipikor.Daerah.Tak.Perlu.Dibubarkan>, diakses 16 Juli 2012.

7 Pengadilan Tipikor Dikembalikan Ke Pusat, <http://suararakyat.net/index.php? option=com_content $\&$ view=article\&id=191:pengadilan-tipikor-dikembalikan-ke-pusat $\&$ catid $=141 \&$ Itemid=577>, diakses 5 Maret 2012 .

8 KY: Bekukan Tipikor Daerah Sementara, <http://pekanbaru.tribunnews.com/ 2011/11/09/ky-bekukan-tipikor-daerah-sementara>, diakses 5 maret 2012.

9 Bubarkan Pengadilan Tipikor Daerah, Pilihan Politik Hukum, <http://nasional.kompas.com/read/2011/11/04/22330494/Bubarkan.Pengadilan.Tipikor.Daerah. Pilihan.Politik.Hukum>, diakses 5 Maret 2012. 
akan menilai kebutuhan, peran, dan kualitas putusan hakim pengadilan tindak pidana korupsi di daerah. Hasil penelitian ini diharapkan dapat membantu memberikan solusi terhadap persoalan pemberantasan tindak pidana korupsi, sekaligus memberikan rekomendasi untuk memperkuat pengadilan tindak pidana korupsi.

\section{Permasalahan}

Pengadilan Tindak Pidana Korupsi dibentuk sebagai upaya untuk memberantas tindak pidana korupsi yang dinilai semakin meluas dan sistematis. Hakim menjadi satu subjek penting dalam upaya pemberantasan tindak pidana korupsi melalui pembentukan pengadilan tindak pidana korupsi. Namun pembentukan Pengadilan Tindak Pidana Korupsi di sejumlah daerah telah menimbulkan kekhawatiran terkait dengan jumlah hakim yang ada, khususnya hakim ad hoc dikaitkan dengan maraknya putusan bebas di sejumlah pengadilan. Penelitian akan mencoba untuk melihat kebutuhan, peran, dan kualitas putusan hakim Pengadilan Tindak Pidana Korupsi melalui pertanyaan penelitian berikut ini:

(1). Apakah hambatan yang akan timbul terkait dengan pembentukan pengadilan tindak pidana korupsi di daerah?

(2). Berapakah jumlah hakim karir dan hakim adhoc yang dibutuhkan oleh pengadilan tindak pidana korupsi untuk melaksanakan tugas fungsi dan kewenangannya?

(3). Apakah putusan hakim pengadilan tindak pidana korupsi pasca pemberlakuan UU No. 46 tahun 2009 tentang Pengadilan Tindak Pidana Korupsi sudah sesuai dengan tujuan pembentukannya?

\section{Tujuan Penelitian}

Adapun tujuan dari penelitian ini adalah untuk menjawab pertanyaan yang dirumuskan sebagai berikut;

(1). Mengetahui dan mempelajari hambatan yang timbul terkait dengan pembentukan pengadilan tindak pidana korupsi di daerah.

(2).Mengetahui jumlah hakim karir dan hakim adhoc yang dibutuhkan oleh pengadilan tindak pidana korupsi untuk melaksanakan tugas fungsi dan kewenangannya agar dapat melaksanakan fungsi pengadilan tipikor secara baik dan benar.

(3). Mengetahui dan mempelajari putusan hakim pengadilan tindak pidana korupsi pasca pemberlakuan UU No. 46 tahun 2009 tentang Pengadilan Tindak Pidana Korupsi sudah sesuai dengan tujuan pembentukannya. 


\section{Kerangka Teori}

Hukum ada dalam segala dimensi kehidupan kita. Ibarat udara, ia tidak terlihat, namun tidak ada sendi kehidupan yang tidak tersentuh hukum.Keberadaan hukum bisa dirasakan tidak hanya ketika seseorang bersentuhan dengan masalah hukum spesifik seperti tersangkut kasus hukum misalnya. Hukum juga tidak hanya bisa dirasakan keberadaannya ketika berinteraksi dengan para penegak hukum (law man) seperti polisi hakim, jaksa ataupun pengacara.

Hukum yang sangat banyak yang tersebar dalam bidang-bidang tertentu itu berlaku secara teratur dan kompleks yang lebih dikenal dengan sistem hukum. Lawrence M. Friedman dalam Bukunya American Law, an Introduction menjelaskan bahwa sistem hukum terdiri dari tiga unsur yang saling berkaitan satu sama lain yakni: Struktur, Substansi dan Budaya hukum. ${ }^{10}$ Pertama, Struktur adalah bagian dari sistem hukum, bisa dikatakan sebagai kerangka hukum yang telah ada yang memberikan bentuk dan batasan secara keseluruhan. Kerangka hukum ini bisa bertahan dalam jangka panjang, bisa terhapus atau tergantikan dan bisa pula bertambah.

Aspek kedua adalah Substansi Hukum, Substansi atau isi dari hukum adalah "inti" dari hukum itu sendiri. Substansi ini bisa berarti dua hal yakni perilaku yang diatur dan produk atau bentuk dari hukum yang mengaturnya. Perilaku yang diatur dalam lalu lintas misanya, dilarang mengendarai kendaraan dalam keadaan pengaruh alkohol. Sedang produk hukum yang mengaturnya adalah undang-undang lalu lintas atau undangundang tindak pidana yang di Indonesia dikenal dengan sebutan Kitab Undang-Undang Hukum Pidana (KUHP). Secara umum pada aspek subtansi hukum, yang hendak ditekankan adalah kondisi ideal yang diharapkan terwujud dengan keberlakuan hukum tersebut. Dengan undang-undang lalu lintas, orang-orang diharapkan bisa berkendara dengan teratur dan mengutamakan keselamatan, Dengan undang-undang perburuhan diharapkan hak tenaga kerja dipenuhi secara layak dan begitu seterusnya.

Aspek ketiga adalah budaya hukum. Setelah ada Struktur dan Substansi hukum, maka tinggal bagaimana sikap orang-orang atas keduanya. Budaya hukum adalah suasana pikiran dan kekuatan sosial yang menentukan bagaimana hukum digunakan, dihindari dan disalahgunakan. ${ }^{11}$ Bagaimana misalnya masyarakat Indonesia yang jika terlibat sengketa hukum, maka hal yang mereka lakukan adalah menempuh jalan damai secara kekeluargaan. Berbeda dengan orang Amerika yang cenderung menyelesaikan semua persoalan di Pengadilan. Itu adalah budaya hukum..

\footnotetext{
${ }^{10}$ Ibid., hal. 7-11.

${ }^{11}$ Ibid., hal. 8.
} 
Teori Friedman yang melahirkan tiga unsur di atas sangat berguna untuk menguraikan sistem hukum yang berlaku di suatu negara. Melalui ketiga unsur tersebut, permasalahan yang diangkat akan diuraikan untuk mencari solusinya. Dari segi Struktur, pengadilan tindak pidana korupsi adalah salah satu bagian dari pengadilan khusus yang berada langsung di bawah Mahkamah Agung. Dalam struktur kekuasaan kehakiman, pengadilan tindak pidana korupsi merupakan bagian dari badan peradilan yang berada di bawah Mahkamah Agung. Pengelolaan sumber daya manusia, anggaran dan birokrasi administrasi pengadilan berada di bawah Mahkamah Agung.

Unsur kedua yakni Substansi hukum. Produk hukum yang memberlakukan pengadilan tindak pidana korupsi telah berlangsung selama tiga periode. Periode pertama Institusi pengadilan tindak pidana korupsi resmi berdiri berdasarkan Undang-Undang No 30 tahun 2002 tentang Komisi Pemberantasan Tindak Pidana Korupsi. Periode kedua, adalah masa transisi yang mana keberadaan pengadilan tindak pidana korupsi diberlakukan terbatas selama tiga tahun semenjak lahirnya putusan Mahkamah Konstitusi No. 012-016-019/PUU-IV/2006. Ketiga, dari unsur budaya hukum. Bagaimana sikap para penegak hukum yang terlibat seperti para hakim ad hoc dan karir dalam memutus perkara. Bagaimana para jaksa melakukan penuntutan. Dan tentunya bagaimana sikap masyarakat atas pengadilan tindak pidana korupsi di masingmasing daerah. Semua itu adalah budaya hukum yang bisa ditangkap dalam penelitian ini.

\section{Metode Penelitian}

Penelitian ini merupakan penelitian normatif empiris yang akan meneliti permasalahan kebutuhan hakim pengadilan tindak pidana korupsi berdasarkan ketentuan peraturan perundang-undangan, peran dan kualitas putusan hakim dalam pemberantasan tindak pidana korupsi. Penelitian terhadap kebutuhan hakim untuk setiap pengadilan tindak pidana korupsi meliputi metode seleksi calon hakim dan kriteria yang ditetapkan oleh panitia seleksi.

Penelitian ini akan menggunakan data sekunder yang didapat melalui penelusuran literatur terkait dengan pembentukan pengadilan tindak pidana korupsi, seleksi calon hakim pengadilan tindak pidana korupsi, baik karir maupun adhoc. Selain itu juga akan meneliti putusan pengadilan tindak pidana korupsi yang sudah berkekuatan hukum tetap. Pengumpulan data dilakukan melalui penelitian kepustakaan, wawancara dan pengamatan ke pengadilan tindak pidana korupsi Jakarta dan Bandung. Data yang telah terkumpul selanjutnya diolah secara sistematis untuk memudahkan melakukan analisis. Metode analisis yang digunakan adalah metode kualitatif, dengan menganalisis berdasarkan ketentuan Perundang-undangan yang mengatur Pengadilan Tindak Pidana Korupsi 
dengan literatur yang membahas mengenai pengadilan. Dengan demikian, hasilnya akan berbentuk suatu analisis deskriptif.

\section{Pembentukan Pengadilan Khusus Tindak Pidana Korupsi dalam Rangka Pemberantasan Tindak Pidana Korupsi}

\section{Pengadilan Tipikor sebagai Suatu Pengadilan Khusus}

Penjelasan Pasal 27 ayat 1 UU No. 48 Tahun 2009 tentang Kekuasaan Kehakiman menjelaskan mengenai yang dimaksud dengan pengadilan khusus:

Yang dimaksud dengan "pengadilan khusus" dalam ketentuan ini, antara lain, adalah pengadilan anak, pengadilan niaga, pengadilan hak asasi manusia, pengadilan tindak pidana korupsi, pengadilan hubungan industrial dan pengadilan perikanan yang berada di lingkungan peradilan umum, serta pengadilan pajak yang berada di lingkungan peradilan tata usaha negara.

Berdasarkan penjelasan tersebut bahwa UU 4 Tahun 2004 tentang Kekuasaan Kehakiman tidak memberikan definisi apa yang dimaksud dengan pengadilan khusus, namun hanya memberikan contoh dari pengadilan khusus itu sendiri. Beberapa pengadilan yang disebutkan itu merupakan pengadilan khusus yang dibentuk sebelum UU No. 27 Tahun 2009 itu lahir. Pengadilan Anak diatur melalui UU No. 3 Tahun 1997 tentang Pengadilan Anak, Pengadilan Niaga diatur melalui Perpu No. 1 Tahun 1998, Pengadilan HAM diatur melalui UU No. 26 Tahun 2000, Pengadilan Hubungan Industrial diatur melalui UU No. 2 Tahun 2004 dan Pengadilan Pajak diatur melalui UU No. 14 Tahun 2002. Dua persamaan lainnya yang menghubungkan antara pengadilan-pengadilan 'khusus', yaitu adanya hakim khusus dengan kompentensi khusus.

Secara filosofis penyusunan UU Pengadilan Tipikor sebagai Pengadilan Khusus dilandaskan pada 3 (tiga) pertimbangan sebagai berikut: ${ }^{12}$

1) Pembentukan Pengadilan Tipikor dengan adanya hakim khusus yang memiliki keahlian bertujuan agar pada masa mendatang, perkara korupsi yang berkaitan dengan masalah pengadaaan barang dan jasa, pertanahan, perpajakan dan yang berhubungan dengan kerusakan SDA, dapat diperiksa dan diadili secara professional dan objektif serta tidak selalu tergantung dengan keterangan dari mereka yang disebut dengan Ahli. Keberadaan hakim adhoc di dalam pengadilan tindak pidana korupsi diharapkan dapat menepis kekhawatiran majelis hakim terpengaruh oleh pendapat ahli tanpa berupaya

\footnotetext{
${ }^{12}$ Ibid., hal. 2.
} 
bersikap kritis. UU No. 8 Tahun 1981 tentang Hukum Acara Pidana menyatakan bahwa dalam menjatuhkan pidana hakim harus mendasarkannya pada sekurang-kurangnya dua alat bukti yang menimbulkan keyakinan padanya bahwa tersangka bersalah.

2) United Nation Convention Againts Corruption (UNCAC) yang telah diratifikasi melalui UU Nomor 7 Tahun 2006 merupakan wujud komitmen pemerintah Indonesia untuk secara regional dan internasional mencegah dan memberantas korupsi, baik disektor publik dan sektor swasta. ${ }^{13}$ Salah satu sasaran reformasi dalam bidang pencegahan korupsi berdasarkan konvensi itu adalah reformasi di bidang perundang-undangan. Di bidang kekuasaan kehakiman telah dilaksanakan dengan pembaruan UU kekuasaan Kehakiman, UU Mahkamah Agung RI dan UU Peradilan Umum. Namun demikian reformasi perundang-undangan yang bersifat umum belum memadai sehingga dalam objek perkara tertentu dan menyangkut subyek hukum tertentu masih memerlukan reformasi baik secara struktural maupun fungsional. Salah satu reformasi yang dimaksud adalah pembentukan Pengadilan Khusus Tindak Pidana Korupsi.

3) Reformasi di bidang peradilan, khususnya untuk tindak pidana korupsi didorong oleh perkembangan perkara korupsi di Indonesia yang semakin meluas dan meningkat serta melibatkan seluruh unsur penyelenggara Negara (eksekutif, legislatif dan yudikatif) di satu sisi, dan di sisi lain tingkat keprcayaan publik terhadap hakim karir semakin merosot. ${ }^{14}$ Kondisi ini memerlukan penanganan khusus yaitu melalui bantuan tenaga ad hoc (non karir) disamping hakim karir. ${ }^{15}$

Diharapkan dengan keberadaan hakim ad hoc, pengadilan tipikor dapat menyelesaikan perkara tipikor yang melibatkan penyelenggara negara dan memupus kecurigaan bahwa dalam perkara tipikor majelis hakim kurang objektif dan selalu memenangkan pihak KPK dan merugikan kepentingan terdakwa.

\section{Pengadilan Tipikor Dalam Praktik}

Pasca pemberlakuan Undang-Undang No 46 Tahun 2009, permasalahan dalam praktik Pengadilan tindak pidana korupsi mulai

\footnotetext{
${ }^{13}$ Ibid.

${ }^{14}$ Ibid

${ }^{15}$ Hasil penelitian "Judicial Integrity" yang dialakukan UNODC dengan MA RI dan BPHN Tahun 2004, menunjukan bahwa, sitem peradilan di Indonesia masih rentan terhadap tindak pidana suap antara penasehat hokum dan penegak hokum, termasuk hakim dan panitera
} pengadilan. 
muncul. Persoalan kualitas putusan sampai pembentukan pengadilan tindak pidana korupsi di daerah semakin mengemuka. Permasalahan mengenai anggaran, sarana dan prasarana, hingga kualitas putusannya tengah menjadi sorotan masyarakat. ${ }^{16}$ Kondisi yang paling mengejutkan dan mendapatkan sorotan publik adalah putusan hakim pengadilan tindak pidana korupsi daerah yang banyak membebaskan para terdakwa kasus korupsi.

Seleksi hakim ad hoc pengadilan tipikor daerah juga terkendala dalam hal anggaran yang sangat terbatas. Untuk menyeleksi hakim ad hoc sebanyak 244 orang hanya dianggarkan dana sebanyak 2,5 milyar rupiah. Sangat kecil dibandingkan dengan KPK yang memilih satu orang dengan dana 2 miliar rupiah. ${ }^{17}$ Persoalan operasional misalnya honorarium hakim ad hoc dan dana penanganan perkara seringkali tidak mencukupi. Pengadilan Tindak Pidana Korupsi di Semarang misalnya, meski telah bersidang tiga bulan sejak Januari-Maret 2011, para hakim ad hoc belum mendapatkan gaji dan tunjangan. Hal yang sama pada Pengadilan Tindak Pidana Korupsi Bandung, yang mana dana operasional dan tunjangan staf dibebankan kepada anggaran PN Bandung karena dana yang dialokasikan terlambat turun. Semua persoalan ini dikhawatirkan akan berimbas kepada kualitas putusan hakim tipikor daerah. Berdasarkan pantauan Hukum online tercatat sedikitnya ada 42 terdakwa korupsi yang divonis bebas oleh pengadilan tipikor daerah. ${ }^{18}$ Jenis putusan yang sangat jarang ditemui ketika putusan PN Tipikor masih terpusat di Jakarta.

Persoalan lain yang muncul adalah perihal pengawasan pengadilan tipikor di daerah. Jika terbentuk 33 pengadilan tindak pidana korupsi di 33 provinsi, maka diperlukan sistem pengawasan yang lebih ketat. Kualitas putusan pengadilan tipikor di daerah dikhawatirkan akan semakin marak pasca putusan bebas di sejumlah daerah. Setidaknya

16 Dalam Laporan tahunan Mahkamah Agung RI disebutkan bahwa persoalan pembentukan pengadilan tipikor salah satunya terkendala oleh ketersediaan Anggaran. Amanah Pasal 35 ayat (1) Undang_undang No 46 tahun 2009 tentang Pengadilan Tindak Pidana Korupsi mengharuskan pembentukan pengadilan tindak pidana korupsi di setiap ibu kota provinsi. Tahun 2010 secara bertahap MA telah merencanakan membentuk 17 pengadilan tipikor di daerah. Namun MA sendiri mengalami keterbatasan anggaran lantaran anggaran MA telah teralokasi secara efektif untuk satuan kerja prioritas yang lainnya. Untuk mengatasi hal itu MA juga telah memintakan tambahan anggaran melalui APBN-P tahun 2010, namun tambahan anggaran juga tak kunjung dikucurkan. Sebagaimana dikutip dari Mahkamah Agung RI, “Laporan Tahunan 2010”, hal. 345.

${ }^{17}$ Kembalikan Pengadilan Tipikor ke PN, <http://www.riauupdate.com/nasional/item/ 171-kembalikan-pengadilan-tipikor-ke-pn.html?tmpl=component\&print=1>, diakses 5 Maret 2012.

18 KY Dukung Pemusatan Pengadilan Tipikor Daerah, <www.hukumonline.com/ berita/baca/lt4eb7c260e07ca/ky-dukung-pemusatan-pengadilan-tipikor>, diakses 5 Maret 2012. 
terdapat 40 putusan yang membebaskan terdakwa yang dilakukan oleh sejumlah pengadilan tipikor di daerah. Menurut Djoko Sarwoko proses pembentukan Pengadilan Tipikor didaerah memang bertahap karena keterbatasan waktu dan biaya yang tidak sedikit. ${ }^{19}$ Hakim berbuat "nakal" bukan disebabkan faktor gaji dan kesejahteraannya, menurut Djoko Sarwoko, permasalahan utama adalah karena persoalan integritas. Selain itu, juga dikarenakan adanya godaan yang begitu kuat, terutama bagi hakim adhoc yang berasal dari advokat yang punya perkara dan keluarga terdakwa. Djoko Sarwoko menilai banyaknya putusan bebas ditingkat pertama dinilainya karena kepincangan yang ada dalam hakim adhoc. Para hakim adhoc tersebut dinilainya tidak banyak mengerti secara mendalam perihal memeriksa perkara dan membuat putusan. Putusan Bebas ditingkat pertama pada umumnya dianulir pada tingkat kasasi dan dijatuhi hukuman penjara. Pengadilan Tipikor Surabaya, Pengadilan Tipikor Bandung, dan Pengadilan Tipikor Semarang adalah pengadilan tipikor yang paling banyak disorot oleh MA. Pengadilan Tipikor Jakarta adalah pengadilan Tipikor yang secara maksimal mendapatkan pengawasan karena merupakan rujukan bagi Pengadilan Tipikor lainnya.

Menurut data dari Mahkamah Agung dalam Laporan Akhir Tahun 2010 dan 2011 ditemukan data Sebagai berikut: ${ }^{20}$

Pada tahun 2010 di Pengadilan Tindak Pidana Korupsi pada Pengadilan Negeri Jakarta Pusat berjumlah 32 perkara, sisa perkara tahun 2009 berjumlah 12 perkara, sehingga jumlah perkara yang ditangani selama 2010 sebanyak 44 perkara. Jumlah perkara pada tahun 2010 turun 51, $56 \%$ dari tahun 2009 yang menerima 64 perkara. Dari keseluruhan perkara selama 2010 tersebut berhasil memutus 34 perkara. Rasio penyelesaian perkara pada Tipikor Jakarta Pusat sebesar 79,07 \%. Pada tahun 2011 perkara yang diterima 33 Pengadilan Tipikor berjumlah 872 perkara, sisa tahun 2010 berjumlah 392 perkara, sehingga jumlah perkara yang ditangani selama 2011 sebanyak 1.264 perkara. Dari keseluruhan perkara yang ditangani itu pengadilan Tindak Pidana Korupsi berhasil memutus 466 perkara (63,13 5).

\footnotetext{
${ }^{19}$ Hasil wawancara dengan Ketua Muda Pidana Khusus MA Djoko Sarwoko.

${ }^{20}$ Laporan tahunan 2010 dan 2011Mahkamah Agung Republik Indonesia.
} 


\begin{tabular}{c|c|c|c|}
\multicolumn{4}{c}{ Jumlah Terdakwa Korupsi yang Diputus oleh Hakim } \\
$\begin{array}{c}\text { Di } \\
\text { Umum } \\
\mathbf{2 0 0 9}\end{array}$ & Tahun & Jumlah Perkara & $\begin{array}{c}\text { Diputus tidak } \\
\text { bersalah }\end{array}$ \\
\cline { 2 - 4 } & 2005 & 78 & $32(41,02)$ \\
& 2006 & 125 & $40(32,00)$ \\
& 2007 & 166 & $95(57,23)$ \\
2008 & 194 & $92(47,42)$ \\
2009 & 199 & $90(45,22)$ \\
& & & \\
\hline & & & $349(45,81)$ \\
\hline
\end{tabular}

Pengadilan selama 2005-

Jumlah Perkara Tindak Pidana Korupsi Jumlah perkara di Pengadilan Tipikor Jakarta 2004-2009 ${ }^{21}$

\begin{tabular}{|c|c|c|}
\hline Tahun & Jumlah Perkara & Putusan \\
\hline 2004-2009 & 105 & $\begin{array}{c}\text { Seluruhnya } \\
\text { dipidana }\end{array}$ \\
\hline
\end{tabular}

Dari 442 perkara Tipikor yang diputus ditingkat Kasasi, Mahkamah Agung memberikan putusan pemidanaan terhadap 90,27 \% perkara. Sedangkan putusan bebas hanya diberikan terhadap 9,73\% perkara. Dari data yang ditemukan oleh Indonesia Corruption Watch (ICW) ditemukan bahwa jumlah terdakwa yang diputus tidak bersalah ini mengalami peningkatan sangat signifikan pertahunnya, yakni dari 2005 ke 2006 mengalami peningkatan sebanyak 10,98\%, dan 2006 ke 2007 mengalami peningkatan 24,52\% dan 2007 ke 2008 mengalami peningkatan 6\%, sedangkan pada 2009 mengalami penurunan menjadi $59,26 \% .^{22}$ Dengan demikian total selama 5 (lima) tahun terakhir sedikitnya ada 884 (delapan ratus delapan puluh empat) terdakwa korupsi yang divonis tidak bersalah oleh pengadilan umum atau sekitar rata-rata $48,83 \%$ dan sisanya diputus

${ }^{21}$ Data ICW 2004-2009.

${ }^{22}$ Baca Hasil Kajian ICW tentang putusan bebas terhadap terdakwa korupsi di Pengadilan Umum. <www.antikorupsi.org> 
bersalah. Kondisi ini jelas sangat berbanding terbalik dengan penanganan perkara tindak pidana korupsi yang ditangani oleh Pengadilan Tipikor. Pengadilan Tipikor telah berhasil memeriksa dan memutus perkara TPK sebanyak 105 (seratus lima) perkara Selama tahun 2004-2009. Keseluruhan dari perkara tersebut divonis bersalah dan tidak ada satupun yang divonis bebas atau lepas. Banyaknya vonis bebas (tidak bersalah) yang terjadi di pengadilan umum, menurut kajian ICW lebih disebabkan karena: (i) terdakwa memang benar-benar tidak terbukti bersalah; (ii) dakwaan yang disusun oleh jaksa lemah atau memang sengaja dilemahkan; (iii) hakim mencari-cari pertimbangan yang menguntungkan terdakwa; (iv) atau karena kombinasi antara dakwaan yang lemah dan hakim yang mencari-cari pertimbangan yang menguntungkan terdakwa. Tiga sebab terakhir yang paling dominan ditemui dari sejumlah putusan hakim yang menjatuhkan vonis tidak bersalah bagi para pelaku korupsi. Pencapaian "prestasi" Tipikor Jakarta sedikit berbeda dengan pencapaian Tipikor di daerah. Pengadilan Tipikor di daerah yang pembentukannya adalah karena amanat undang-undang sedikit tercoreng oleh beberapa kasus yang membebaskan terdakwa pelaku tindak pidana korupsi.

Kondisi demikian ini bisa disebabkan oleh lemahnya pengawasan internal yang dilakukan oleh Mahkamah Agung terhadap para hakim di semua lingkungan peradilan. Pada sisi lain keberadaan Komisi Yudisial (KY) sebagai pengawas eksternal yang perlu ditingkatkan.

\section{Data Perkara Pengadilan Tipikor Bandung ${ }^{23}$}

\begin{tabular}{|c|c|c|c|c|}
\hline & Rincian & \multicolumn{2}{|c|}{ Tahun } & Keterangan \\
\hline & & 2011 & Per-agustus 2012 \\
\hline 1 & Perkara putus & $\begin{array}{c}106 \\
\text { perkara }\end{array}$ & 56 perkara & \\
\hline 2 & $\begin{array}{c}\text { Perkara belum } \\
\text { putus }\end{array}$ & 0 & 32 & \\
\hline 3 & Banding & 30 & 32 & \\
\hline 4 & Kasasi & 19 & 40 & \\
\hline 5 & BHT & 79 & 14 & \\
\hline 6 & Bebas Murni & 11 & 1 & \\
\hline 7 & Bebas Onslagh & 8 & 1 & \\
\hline 8 & $\begin{array}{c}\text { Batal demi } \\
\text { hukum }\end{array}$ & 3 & 0 & \\
\hline 9 & Kadaluarsa & 0 & 0 & \\
\hline 10 & Dikembalikan & 1 & 0 & \\
\hline
\end{tabular}

23 Data merupakan data resmi yang dikeluarkan Pengadilan Tipikor Bandung per Agustus 2012. 


\section{Hambatan Seputar Pengadilan Tipikor}

Pengadilan Tipikor pada awalnya diharapkan mampu menjawab keinginan masyarakat Indonesia guna mewujudkan suatu Pengadilan Khusus bagi para pelaku tindak pidana korupsi di Indonesia. Sejak awal pembentukannya sampai saat ini, tercatat berbagai masalah telah dijumpai. Pada bagian terdahulu, ada keinginan dari beberapa ahli untuk mewujudkan penguatan di Pengadilan Tipikor ini. Berikut adalah beberapa hasil temuan yang dilapangan yang dilakukan oleh tim peneliti di Pengadilan Tipikor Jakarta dan Pengadilan Tipikor Bandung.

\section{a. Pembentukan dan Posisi Pengadilan}

Setelah Putusan MK No. 012-016-019/PUU-IV/2006 yang menyatakan pasal 53 UU No. 30 Tahun 2002 bertentangan dengan konstitusi maka kasus korupsi tidak bisa diadili di dua pengadilan yang berbeda yaitu Pengadilan tipikor Jakarta dan pengadilan umum. Pembentukan Pengadilan Tindak Pidana Korupsi (Tipikor) sebagai pengadilan yang memiliki kompetensi untuk memeriksa perkaraperkara TIpikor dilatarbelakangi oleh semangat pembaruan untuk memberantas Tindak Pidana Korupsi yang marak di Indonesia.Hal ini tercermin dalam UU No. 30 Tahun 2002 tentang Komisi Pemberantasan Tindak Pidana Korupsi. Pada tahun 2006, melalui putusan Mahkamah Konstitusi Nomor 012-016-019/PUU-IV/2006 tanggal 19 Desember 2006 Pembentukan Pengadilan Tipikor dalam UU 30 Tahun 2002 dinyatakan bertentangan dengan UUD 1945. Penbentukan Pengadilan Tipikor harus dibentuk dengan undangundang khusus yang terpisah dari UU 30 Tahun 2002, dengan demikian lahirlah UU No. 46 Tahun 2009 tentang Pengadilan Tindak Pidana Korupsi.

Pengadilan Tipikor harus sudah terbentuk di 33 provinsi di Indonesia pada akhir 2011. Dengan demikian pada awal tahun 2012 seharusnya sudah ada 33 pengadilan tindak pidana korupsi daerah. Sorotan tajam dari masyarakat mulai muncul ketika beberapa pengadilan tindak pidana korupsi di daerah memutus bebas sejumlah terdakwa pelaku tindak pidana korupsi. Semenjak itulah masyarakat mempertanyakan manfaat pembentukan pengadilan tipikor di daerah yang memperlihatkan secara gamblang ada sesuatu yang tidak benar dalam proses peradilannya.

Beberapa orang ahli berpendapat untuk mengevaluasi keberadaan pengadilan tindak pidana korupsi terkait beberapa putusan bebas para terdakwa dan dugaan penerimaan suap oleh beberapa hakim Tipikor di daerah. Berdasarkan hasil wawancara dengan wakil direktur LeIP, hal ini merupakan suatu konsekuensi dari adanya Putusan MK tahun 2006. ${ }^{24}$ Tafsiran Putusan MK 
mengakibatkan munculnya UU Pengadilan Tipikor yang menyatakan bahwa pengadilan tipikor adalah satu-satunya pengadilan yang berwenang mengadili perkara korupsi. Hal ini merupakan konsekuensi dari dihapuskannya dualisme pengadilan yang mengadili kasus korupsi. Akibatnya tentu jumlah pengadilan tipikor tidak bisa hanya 1 , karena tidak mungkin seluruh perkara korupsi (yang bukan merupakan kompentensi pengadilan militer maupun anak) di adili hanya di satu pengadilan saja.

Mengenai soal tafsir kata "dalam" dan "dengan", oleh karena di dalam ketentuan tersebut dinyatakan bahwa pengadilan khusus diatur "dengan" undang-undang maka MK menafsirkan bahwa rumusan kata "dengan UU" mengandung arti bahwa pengaturan mengenai pengadilan khusus harus diatur dengan undang-undang tersendiri, tidak boleh hanya sekedar di atur dalam undang-undang yang tidak secara khusus mengatur pengadilan khusus tersebut. Dan oleh karena pengaturan pengadilan tipikor saat itu ada di dalam UU KPK bukan UU Pengadilan Tipikor maka hal tersebut dipandang bertentangan dengan konstitusi.Walaupun tidak setuju dengan masalah tafsir itu, menurutnya Putusan MK wajib dihormati.

Keberadaan pengadilan tindak pidana korupsi di daerah ternyata menyulitkan dari segi teknis pelaksanaannya. Hal ini diakui oleh Yudi Kristiana yang menilai bahwa faktor non teknis banyak menyulitkan penuntut dari KPK. ${ }^{25}$ Faktor jarak yang sangat luas di Indonesia menyebabkan kesulitan tersendiri dalam rangka mengadakan tuntutan. Satu provinsi bisa terdiri dari beberapa puluh Kejaksaan Negeri. Karena terbatasnya penyidik dan penuntut dari KPK. Disamping itu faktor sarana dan prasarana belum didukung dengan baik. Menurutnya pengawasan masyarakat pada akhirnya akan menjadi sedikit kendor. Menurut Yudi Kristiana, masalah anggaran penuntutan tidak terlalu berpengaruh di KPK, namun akan sangat berpengaruh ketika Kejaksaan Agung yang akan melakukan upaya penuntutan. Karena terbatasnya dana anggaran. Menurutnya KPK tidak perlu ada jika Kejaksaan diperbaharui dengan peningkatan anggaran khususnya dalam melakukan penuntutan mengingat KPK hanya ada satu di Jakarta, sementara Kejaksaan ada disetiap daerah di Indonesia.

Menurut Ketua Pengadilan Negeri Bandung, Singgih Budi Prakoso, faktor sarana dan sarana sangat berpengaruh. ${ }^{26}$ Namun

${ }^{24}$ Selain menjabat menjadi wakil direktur Leip, Arsil merupakan tokoh penggiat anti korupsi dan juga terlibat dalam koalisi masyarakat sipil dalam pembentukan RUU Pengadilan Tipikor. Wawancara dilakukan pada bulan agustus 2012.

${ }^{25}$ Yudi Kristiana merupakan seorang jaksa yang pada saat ini diperbantukan menjadi Jaksa Penuntut di KPK.Beberapa kali menyidang kasus Tipikor.Wawancara dilakukan pada bulan agustus 2012 . 
Pengadilan Negeri Bandung terus berbenah mengenai masalah infrastruktur ini. Mengenai ruang sidang, Pengadilan Negeri Bandung masih menggunakan Ruang sidang Pengadilan Umum karena belum ada anggaran untuk membangun ruangan. Pengadilan Negeri Bandung baru menyediakan ruangan bagi para hakim adhoc secara terpisah. Menurut Panitera PN Bandung, pengadilan belum siap untuk melakukan sidang Pengadilan Khusus Korupsi. Ruang pengadilan yang kurang dan jauh dari kata layak juga dialami oleh Pengadilan Tipikor Jakarta. Terlebih letaknya di Ibukota dan sering mendapat sorotan media, namun sarana dan prasarananya jauh dari kata memadai.

\section{b. Independensi dan Akuntabilitas}

Untuk menjamin efektifitas dan konsistensi Pengadilan Tipikor dalam proses mengadili perkara korupsi, salah satunya diperlukan aturan yang mendukung proses administrasi perkara korupsi. Terkait dengan hal tersebut, Pasal 22 (1) UU No 46 Tahun 2009 Tentang Pengadilan Korupsi yang mengamanatkan bahwa pada Pengadilan Tipikor dapat ditetapkan adanya kepaniteraan khusus yang dipimpin oleh seorang panitera. Selanjutnya Pasal 23 menyatakan bahwa ketentuan lebih lanjut mengenai tugas, tanggung jawab, susunan organisasi, dan tata kerja kepaniteraan khusus Pengadilan Tindak Pidana Korupsi diatur dengan Peraturan Mahkamah Agung. Menindaklanjuti amanat UU Pengadilan Tipikor, pada 20 Desember 2010 Mahkamah Agung menetapkan Peraturan Mahkamah Agung RI Nomor 01 Tahun 2010 (Perma 01/2010) tentang Struktur Organisasi Kepaniteraan dan Susunan Majelis Hakim Serta Keterbukaan pada Pengadilan Tindak Pidana Korupsi.

Namun kenyataan di lapangan masalah panitera masih menjadi masalah tersendiri. Para panitera yang ada adalah para panitera dari pengadilan umum yang "diperbantukan" dengan SK Ketua PN masing-masing dengan tunjangan yang berbeda. Selain itu, pola kejahatan di dalam pengadilan melalui Panitera menjadi trend tersendiri. Hal ini diamini oleh Ketua Muda Pidana Khusus, Djoko Sarwoko. Panitera menjadi salah satu gerbang pintu masuk bagi para pelaku kejahatan di pengadilan. Permasalahan yang terjadi tidak hanya ada di hakim atau Jaksa, namun telah juga bergeser pada level panitera.

\section{c. Pola Rekrutmen dan Peningkatan Kapasitas Kompetensi}

Rekruitmen hakim pengadilan tindak pidana korupsi, terutama hakim ad hoc, perlu diperbaiki agar mendapatkan calon yang

${ }^{26}$ Singgih Budi Prakoso, Kepala Pengadilan Negeri Bandung, Yang membawahi Pengadilan Tipikor Bandung. Wawancara dialakukan bulan September 2012. 
berkualitas. Kurangnya sumber daya manusia dari calon hakim adhoc Tipikor ditambah kurangnya peningkatan kompetensi menjadi pendukung akan adanya permasalahan mengenai Pengadilan Tipikor. Menurut Arsil, Satu hal yang kritikal terkait pengadilan tipikor adalah hakim ad hoc. Sebenarnya hal ini merupakan perbedaan mendasar antara pengadilan biasa (yang mengadili perkara korupsi) dengan pengadilan tipikor, yang mana khusus untuk pengadilan tipikor majelis hakim yang menangani perkara korupsi tidak hanya terdiri dari hakim (karir) namun juga hakim ad hoc, bahkan di UU yang lama (UU KPK) komposisinya lebih banyak dari hakim karir, yaitu 3 hakim ad hoc dan 2 hakim (karir). Oleh karena perbedaan utama terletak pada keberadaan hakim ad hoc, maka yang menjadi isu adalah bagaimana mendapatkan hakim ad hoc yang baik. Lebih lanjut menurut Arsil, jika seandainya kita menganggap hakim-hakim (karir) yang ada saat ini buruk, tidak menjadi jaminan bahwa hakim ad hoc akan lebih baik dari hakim-hakim (karir) tersebut. Hakim ad hoc pada dasarnya hanyalah orang yang selama ini tidak berprofesi sebagai hakim yang kemudian diberikan tanggung jawab untuk sementara waktu untuk menjadi hakim untuk jenis-jenis perkara tertentu dan untuk periode waktu tertentu. Dengan pengertian seperti ini maka kita tidak bisa dengan serta merta menyatakan hakim ad hoc pasti lebih baik dari hakim, kecuali jika kita menganggap semua orang Indonesia selain hakim (karir) lebih baik dari hakim, yang mana pandangan tersebut tentunya sangatlah naif kalau tidak bisa dibilang kurang berkualitas.

Arsil menambahkan kalau setidaknya ada dua variabel yang penting untuk mendapatkan hakim ad hoc yang baik, pertama resources atau kualitas calon-calon atau orang yang tidak hanya tersedia namun juga mau berpartisipasi sebagai hakim adhoc, dan yang kedua yang tak kalah pentingnya bagaimana proses seleksi hakim adhoc itu sendiri. Kedua hal tersebut sama-sama pentingnya, percuma kita memiliki sumber daya calon hakim ad hoc yang baik jika mekanisme seleksinya buruk. Dan sebaliknya, percuma kita memiliki mekanisme seleksi hakim ad hoc yang baik, yang transparan, akuntabel, partisipatif kalau kualitas calon-calon yang bersedia mendaftar masih rendah. Sorotan publik masih sangat terasa pada hasil. Pada setiap proses seleksi hakim ad hoc, terutama hakim adhoc Tipikor, Mahkamah Agung melibatkan kalangan organisasi masyakarat anti korupsi, setidaknya hingga tahun 2010 yang lalu yaitu rekrutmen hakim ad hoc pertama paska disahkannya UU No. 46 Tahun 2009 yang menjadi dasar keberadaan Pengadilan Tipikor yang sekarang. Peran kalangan civil society tersebut diberikan bahkan hingga masuk menjadi bagian dari Panitia Seleksi.Tercatat Bambang Widjojanto dan Mas Achmad Santosa pernah duduk di dalamnya. Namun menurut tenaga ahli dari Komisi Yudisial, Firmansyah Arifin, proses pelibatan unsur masyarakat hanya sekali 
dilakukan Mahkamah Agung, yaitu pada tahap pertama seleksi calon hakim adhoc Tipikor. ${ }^{27}$ Hal ini menurut Firmansyah menjadi kelemahan tersendiri. Hasil hakim ad hoc tahap pertama masih memiliki penilaian yang bagus dibanding tahap berikutnya. Disamping itu Komisi Yudisial tidak terlibat dalam proses seleksi hakim ad hoc. Maka dari itu menurut Firmansyah, pada proses seleksi yang keempat ini, Komisi Yudisial akan melibatkan diri karena Komisi Yudisial memiliki kewenangan dalam rangka proses seleksi hakim. Dengan rendahnya animo masyarakat, maka harapan untuk mendapatkan hakim ad hoc sesuai yang diharapkan akan sulit. Sementara itu penghapusan dualisme pengadilan yang mengadili perkara korupsi maka kebutuhan pengadaan hakim ad hoc semakin membengkak. Kondisi semacam ini tengah terjadi saat ini.

\section{d. Hukum Acara Persidangan}

Perbedaan mendasar antara pengadilan biasa (yang mengadili perkara korupsi) dengan pengadilan tipikor, dimana khusus untuk pengadilan tipikor majelis hakim yang menangani perkara korupsi tidak hanya terdiri dari hakim (karir) namun juga hakim ad hoc, bahkan di UU yang lama (UU KPK) komposisinya lebih banyak dari hakim karir, yaitu 3 hakim ad hoc dan 2 hakim (karir).Jika seandainya pun kualitas suatu pengadilan diukur dari prosentase putusan bebas atau bersalah, banyak variabel yang harus diperhitungkan untuk menilainya. Menurut Arsil, dalam konteks pengadilan tipikor yang hanya ada di Jakarta pada saat itu tidak otomatis kita bisa menilai bahwa vonis-vonis bersalah tersebut terjadi karena eksistensi pengadilan tipikor itu sendiri, setidaknya ada 3 variabel lainnya yang ikut menentukan 'keberhasilan' pengadilan tipikor saat itu. Variabel-variabel tersebut yaitu:

1. Kualitas KPK sendiri sebagai institusi yang berwenang mengajukan tuntutan di pengadilan tipikor,

2. Besarnya sorotan publik (media) di pengadilan tipikor karena pengadilan tipikor hanya ada di Jakarta serta umumnya kasus-kasus yang di adili memang merupakan kasus-kasus yang menarik perhatian publik,

3. Kualitas para hakim (khususnya hakim ad hoc) yang ada saat itu.

Jika kita melihat variable tersebut, maka hal tersebut akan sulit ditemui jika kita melihat Pengadilan Tipikor yang ada di daerah. Menurut KPN Bandung, majelis hakim mempunyai kemerdekaan tersendiri dalam memutus suatu perkara. Hal itu harus dihargai,

27 Firmansyah adalah tenaga ahli dari Komisi Yudisial, merupakan aktivis dunia peradilan yang terlibat dalam koalisi masyarakat dalam rang ka pembentukan UU Pengadilan Tipikor. wawancara dilakukan pada bulan Juli. 
walau begitu kualitas putusan terlihat dari beberapa hakim. Pengalaman membuat putusan dan pengetahuan yang dimiliki hakim karir menjadi keunggulan tersendiri. Namun pihak Pengadilan Tipikor Bandung berupaya untuk menyamakan mutu terutama kepada hakim ad hoc. Pelatihan diwajibkan kepada para hakim ad hoc yang secara khusus didampingi oleh hakim karir untuk melakukan semacam tentir. Namun hal ini menurut pendapat penulis masih kurang. Pelatihan terhadap para hakim ad hoc hanya dilakukan sekali (hanya berupa semacam penataran oleh MA). Menurut Jaksa KPK, Yudi Kristiana, kecenderungan di Pengadilan Tipikor Jakarta yang belum pernah memberikan putusan bebas kepada terdakwa, bisa dimanfaatkan pihak-pihak yang tidak bertanggungjawab. Upayaupaya tersangka dari daerah yang tidak ingin perkaranya dilakukan di Pusat bisa menjadi "mata pencaharian" tersendiri bagi para Aparat Penegak Hukum yang tidak bertanggungjawab. Hal ini disetujui oleh Djoko Sarwoko. Umumnya para tersangka yang mempunyai kekuatan politis sering berupaya menghubungi para Hakim Agung di MA supaya kasusnya tidak disidangkan di Jakarta. Menurut Direktur LBH Bandung, Arip Yogiawandi, perkara kasus korupsi di Bandung yang janggal penanganannya sering kali berasal dari tersangka yang mempunyai kekerabatan dengan kepala daerah. Umumnya mereka meminta penangguhan penahanan. ${ }^{28}$

\section{Peran Dan Kedudukan Hakim Dalam Pengadilan Tindak Pidana Korupsi}

\section{Rekrutmen Hakim di Setiap Lingkungan Peradilan}

Pasal 19 ayat (2) UU No. 48 Tahun 2009 tentang Kekuasaan Kehakiman menetapkan bahwa Hakim dan hakim konstitusi adalah pejabat negara yang melakukan kekuasaan kehakiman untuk dapat diangkat sebagai hakim di Peradilan umum, Pasal 14 ayat (1) UU No. 49 Tahun 2009 Tentang Perubahan Kedua Atas Undang-Undang Nomor 2 Tahun 1986 Tentang Peradilan Umum seseorang harus memenuhi syarat sebagai berikut:

a. Warga negara Indonesia;

b. Bertakwa kepada Tuhan Yang Maha Esa;

c. Setia kepada Pancasila dan Undang-Undang Dasar Negara Republik Indonesia tahun 1945;

d. Sarjana hukum;

e. Lulus pendidikan hakim;

f. Mampu secara rohani dan jasmani untuk menjalankan tugas dan kewajiban;

\footnotetext{
${ }^{28}$ Wawancara pada agustus 2012 di LBH Bandung.
} 
g. Berwibawa, jujur, adil, dan berkelakuan tidak tercela;

h. Berusia paling rendah 25 (dua puluh lima) tahun dan paling tinggi 40 (empat puluh) tahun; dan

i. Tidak pernah dijatuhi pidana penjara karena melakukan kejahatan berdasarkan putusan pengadilan yang telah memperoleh kekuatan hukum tetap.

Syarat tersebut juga berlaku bagi Hakim yang diangkat pada Peradilan Tata Usaha Negara. Pasal 14 UU No. 51 Tahun 2009 Tentang Perubahan Kedua Atas Undang-Undang Nomor 5 Tahun 1986 Tentang Peradilan Tata Usaha Negara mengatur hal yang sama dengan ketentuan bagi Hakim pada Peradilan Umum. Sedangkan untuk menjadi hakim di Peradilan Agama, pada Pasal 13 ayat (1) UU No. 50 Tahun 2009 Tentang Perubahan Kedua Atas Undang-Undang Nomor 7 Tahun 1989 Tentang Peradilan Agama syarat tersebut ditambahkan (1) Harus Beragama Islam; (2) sarjana syari'ah, sarjana hukum Islam atau sarjana hukum yang menguasai hukum Islam.

Ketentuan dan syarat untuk dapat diangkat menjadi Hakim Militer, berbeda dengan hakim pada lingkup peradilan lainnya (Peradilan Umum, Tata Usaha Negara, Agama) karena diharuskan berasal dari Tentara Nasional Indonesia (TNI). Pada Pasal 18 UU No. 31 Tahun 1997 tentang Peradilan Militer, seorang Prajurit yang akan diangkat sebagai Hakim Militer harus memenuhi syarat:

a. Bertakwa kepada Tuhan Yang Maha Esa;

b. Setia dan taat kepada Pancasila dan Undang-Undang Dasar 1945;

c. Tidak terlibat partai atau organisasi terlarang;

d. Paling rendah berpangkat Kapten dan berijazah Sarjana Hukum;

e. Berpengalaman di bidang peradilan dan/atau hukum; dan

f. Berwibawa, jujur, adil, dan berkelakuan tidak tercela.

Selain keempat lingkungan Peradilan yang ada berdasarkan UU No. 48 Tahun 2009 tentang Kekuasaan Kehakiman, terdapat pula pengadilan khusus yang dibentuk dibawah salah satu lingkungan Badan Peradilan tersebut. Penjelasan Pasal 27 ayat (1) UU No. 48 Tahun 2009 tentang Kekuasaan Kehakiman menjelaskan bahwa yang dimaksud dengan "pengadilan khusus" antara lain adalah pengadilan anak, pengadilan niaga, pengadilan hak asasi manusia, pengadilan tindak pidana korupsi, pengadilan hubungan industrial dan pengadilan perikanan yang berada di lingkungan peradilan umum, serta pengadilan pajak yang berada di lingkungan peradilan tata usaha negara. Syarat untuk menjadi hakim pada pengadilan khusus tersebut berbeda satu dengan lainnya. Berikut beberapa contoh syarat untuk seorang dapat diangkat menjadi hakim pada pengadilan khusus. 


\section{a. Pengadilan Anak}

UU No. 3 Tahun 1997 Tentang Pengadilan Anak pada Pasal 10 diatur syarat sebagai berikut:

a. Telah berpengalaman sebagai hakim di pengadilan dalam lingkungan Peradilan Umum; dan

b. Mempunyai minat, perhatian, dedikasi, dan memahami masalah anak.

Dalam Penjelasannya, yang dimaksud dengan "mempunyai minat, perhatian, dedikasi, dan memahami masalah anak" adalah memahami:

1. Pembinaan anak yang meliputi pola asuh keluarga, pola pembinaan sopan santun, disiplin anak, serta melaksanakan pendekatan secara efektif, afektif, dan simpatik;

2. Pertumbuhan dan perkembangan anak; dan

3. Berbagai tata nilai yang hidup di masyarakat yang mempengaruhi kehidupan anak.

\section{b. Pengadilan Hak Asasi Manusia}

UU No. 26 Tahun 2000 tentang Pengadilan HAM mengatur adanya hakim ad hoc dalam menyidangkan perkara terkait pelanggaran HAM. UU tersebut tidak memberikan persyaratan untuk seorang hakim karir untuk dapat menyidangkan perkara HAM, tetapi mengatur ketentuan untuk hakim ad hoc. Untuk dapat diangkat menjadi Hakim ad hoc berdasarkan Pasal29 UU No. 6 Tahun 2000 tenang Pengadilan HAM harus memenuhi syarat:

1. Warga negara RI;

2. Bertaqwa kepada Tuhan Yang Maha Esa;

3. Berumur sekurang-kurangnya 45 (empat puluh lima) tahun dan paling tinggi 65 (enam puluh lima) tahun;

4. Berpendidikan sarjana hukum atau sarjana lain yang mempunyai keahlian di bidang hukum;

5. Sehat jasmani dan rohani;

6. Berwibawa, jujur, adil, dan berkelakukan tidak tercela;

7. Setia kepada Pancasila dan Undang-Undang Dasar 1945; dan

8. Memiliki pengetahuan dan kepedulian di bidang hak asasi manusia

\section{c. Pengadilan Hubungan Industrial}

UU No. 2 Tahun 2004 Tentang Pengadilan Hubungan Industrial pada Pasal63 hanya mengatur ketentuan untuk pengangkatan hakim 
ad hoc. Untuk dapat diangkat menjadi Hakim Ad-Hoc pada Pengadilan Hubungan Industrial dan Hakim Ad-Hoc pada Mahkamah Agung, harus memenuhi syarat sebagai berikut:

1. Warga negara indonesia;

2. Bertaqwa kepada tuhan yang maha esa;

3. Setia kepada pancasila dan undang-undang dasar negara republik indonesia tahun 1945;

4. Berumur paling rendah 30 (tiga puluh) tahun;

5. Berbadan sehat sesuai dengan keterangan dokter;

6. Berwibawa, jujur, adil, dan berkelakuan tidak tercela;

7. Berpendidikan serendah-rendahnya strata satu (S.1) kecuali bagi hakim ad hoc pada mahkamah agung syarat pendidikan sarjana hukum; dan

8. Berpengalaman di bidang hubungan industrial minimal 5 tahun.

\section{Rekrutmen Hakim Dalam Pengadilan Tindak Pidana Korupsi}

Salah satu karakterisitik dari Pengadilan Tindak Pidana Korupsi (Tipikor) yang membedakannya dengan pengadilan Negeri dalam memeriksa perkara korupsi adalah komposisi hakim. Pada awal pembentukan Pengadilan Tipikor, diatur dalam Pasal 56 ayat (1) Undang-undang No. 30 Tahun 2002 Tentang Komisi Pemberantasan Korupsi mengenai hakim yang memeriksa perkara korupsi di Pengadilan Tindak Pidana Korupsi terdiri atas hakim Pengadilan Negeri, sering disebut juga hakim Karir dan Hakim ad hoc.

\section{a. Rekrutmen Hakim Karir pada Pengadilan Tindak Pidana Korupsi}

Pengertian mengenai Hakim Karir dalam UU Pengadilan Tindak Pidana Korupsi, diatur dalam Pasal 1 angka (2) adalah hakim pada Pengadilan Negeri, Pengadilan Tinggi, dan Mahkamah Agung yang ditetapkan sebagai hakim tindak pidana korupsi. ${ }^{29}$ Penetapan hakim karir untuk ditugaskan sebagai hakim tipikor harus memenuhi beberapa persyaratan yang diatur dalam Pasal 11 UU No. 46 Tahun 2009 tentang Pengadilan Tindak Pidana Korupsi. Beberapa persyaratan yang harus calon penuhi sebagai berikut:

1. Berpengalaman menjadi hakim sekurang-kurangnya selama 10 (sepuluh) tahun;

2. Berpengalaman menangani perkara pidana;

\footnotetext{
${ }^{29}$ Indonesia, Undang Undang Pengadilan Tindak Pidana Korupsi, UU No. 46 Tahun 2009, LN No. 155 Tahun 2009, TLN No. 5074, Pasal 1 angka (2).
} 
3. Jujur, adil, cakap, dan memiliki integritas moral yang tinggi serta reputasi yang baik selama menjalankan tugas;

4. Tidak pernah dijatuhi hukuman disiplin dan/atau terlibat dalam perkara pidana;

5. Memiliki sertifikasi khusus sebagai hakim tindak pidana korupsi yang dikeluarkan oleh Mahkamah Agung; dan

6. Telah melaporkan harta kekayaannya sesuai dengan ketentuan peraturan perundang-undangan.

Mahkamah Agung hingga saat ini belum memiliki aturan internal mengenai Sertifikasi Hakim pada pengadilan Tindak Pidana Korupsi. Berbeda dengan Sertifikasi Hakim Lingkungan yang memiliki acuan sejak disahkannya SK No. 134/KMA/SK/IX/2011 tentang Sertifikasi Hakim Lingkungan. Hal ini juga diakui oleh Djoko Sarwoko, Ketua Muda Pidana Khusus Mahkamah Agung, yang menyatakan bahwa saat ini tengah disusun surat edaran yang akan digunakan sebagai pedoman dan persyaratan bagi hakim karir untuk mendapatkan sertifikasi hakim pengadilan tindak pidana korupsi. ${ }^{30}$ Menurut Firmansyah Arifin, rekrutmen hakim karir oleh MA ini mengalami kemunduran di UU Pengadilan tipikor dibanding UU Komisi Pemberantasan Korupsi. ${ }^{31}$ Pada Pasal 56 UU No. 30 tahun 2002 tentang KPK diatur untuk perekrutan Hakim yang berasal dari karir wajib diumumkan dulu kepada publik, sehingga publik dapat memberikan masukan.

Adanya proses dan persyaratan untuk menjadi Hakim Tipikor ini bertujuan agar terdapat spesialisasi atau keahlian khusus mengenai tindak pidana korupsi dan tindak pidana lain yang berasal dari tindak pidana korupsi seperti pencucian uang. Kebutuhan untuk spesialisasi ini, menurut Anthony Hol dan Marc Loth, dikarenakan adanya kebutuhan agar tidak terjadi ketimpangan pemahaman yang dimiliki hakim dengan pengacara/ahli hukum lainnya. ${ }^{32}$ Kebijakan untuk menentukan hakim spesialis ini sejalan dengan arah Cetak Biru Mahkamah Agung dengan membentuk Sistem Kamar yang bertujuan untuk mengelola konsistensi putusan sehingga dapat menjaga kesatuan hukum. Spesialisasi hakim ini juga bertujuan untuk meningkatkan kualitas putusan dan percepatan penanganan perkara

${ }^{30}$ Wawancara Djoko Sarwoko, 28 Juni 2012.

31 Focus Group Discussion: Evaluasi Kinerja Pengadilan Tindak Pidana Korupsi, diselenggarakan oleh MaPPI FHUI di Hotel Morissey, Jakarta, 31 Agustus 2012.

32 Anthony Hol dan Marc Loth, "Reshaping Justice: Judicial Reform and Adjudication in The Netherlands", dalam Luhut M.P. Pangaribuan, "Lay Judges \& Hakim Ad hoc (Suatu Studi Teoritis Mengenai Sistem Peradilan Pidana Indonesia)”, (Jakarta: FHUI \& Papas Sinar Sinanti, 2009), Hlm. 397 
karena suatu perkara diperiksa dan diputus oleh Hakim yang memiliki keahlian tertentu. Terhadap kecepatan penanganan perkara, Pasal 10 ayat (3) UU Pengadilan Tindak Pidana Korupsi membebaskan hakim yang menangani perkara Tindak Pidana Korupsi untuk menangani perkara-perkara lainnya. ${ }^{33}$

\section{b. Hakim Ad hoc Pengadilan Tindak Pidana Korupsi}

Hakim ad hoc (Non karir) adalah hakim yang bertugas untuk sementara waktu yang memiliki keahlian dan pengalaman di bidang tertentu untuk memeriksa, mengadili, dan memutus suatu perkara yang pengangkatannya diatur dalam undang-undang. ${ }^{34}$ Keberadaan hakim ad hoc mulai diperkenalkan dalam Pengadilan Tata Usaha Negara (PTUN) Pada tahun 1986, lalu kemudian berkembang pada Pengadilan khusus seperti Pengadilan Niaga, Pengadilan HAM, Pengadilan Perikanan, dan Pengadilan Hubungan Industrial.

Hakim ad hoc dalam Pengadilan tindak pidana korupsi ini diangkat dan diberhentikan oleh Presiden atas usul Ketua Mahkamah Agung (MA). Konsep Undang-undang No. 30 Tahun 2002 hakim ad hoc adalah ahli di bidang hukum, yaitu seseorang yang bersarjana hukum atau sarjana lain dan memiliki keahlian dan pengalaman di bidang hukum. Ada 5 (lima) variasi dari hakim ad hoc: ${ }^{35}$

a. Hakim ad hoc yang mempunyai pengetahuan secara umum di bidang hukum dengan periode pengalaman tertentu yang dapat diangkat untuk satu periode tertentu;

b. Hakim ad hoc yang dianggap memiliki pengetahuan tertentu yang diangkat secara tetap untuk satu periode waktu tertentu, tetapi keikutsertaannya di Pengadilan tergantung dari para pihak yang bersengkaeta, misal Hakim ad hoc pada Pengadilan Niaga;

c. Hakim ad hoc yang dianggap memiliki pengetahuan tertentu di bidang hukum tertentu yang diangkat secara tetap untuk satu periode waktu tertentu. Misalnya hakim pada Pengadilan Hubungan Industrial dan Pengadilan Perikanan;

d. Hakim yang tidak berasal dari karir tetapi hakim tersebut ditunjuk oleh Menteri terkait tertentu untuk menjadi hakim di Pengadilan dalam suatu periode tertentu. Misalnya hakim di Pengadilan Pajak;

\footnotetext{
${ }^{33}$ Indonesia, Undang-Undang Pengadilan Tindak Pidana Korupsi, Op.Cit., Pasal 10 ayat (3).

${ }^{34}$ Pasal 1 angka 6 UU No. 49 tahun 2009.

${ }^{35}$ Ibid., hal. 41.
} 
e. Hakim ad hoc yang ditunjuk menjadi hakim dalam satu kasus tertentu yang didasarkan pada keahliannya dalam menangani suatu kompleksitas masalah tertentu saja.

Hakim ad hoc (non-karir) menjadi sebuah kebutuhan pada awal pembentukan Pengadilan Tipikor mengingat kepercayaan publik yang tengah menurun terhadap hakim karir. ${ }^{36}$ Pengaturan hakim ad hoc pada awalnya diatur dalam memeriksa perkara korupsi lahir dari Undang-undang No. 30 Tahun 2002 tentang Komisi Pemberantasan Korupsi, sebagai salah satu upaya pemberantasan korupsi. Dalam konsiderans Undang-undang KPK butir b disebutkan "bahwa lembaga pemerintah yang menangani perkara tindak pidana korupsi belum berfungsi secara efektif dan efisien dalam pemberantasan korupsi”. Dengan demikian, latar belakang masuknya hakim ad hoc di Pengadilan Tindak Pidana Korupsi karena lemahnya kredibilitas dan integritas lembaga yang mengadili perkara korupsi sebelumnya termasuk pihak-pihak yang terlibat didalamnya terutama hakim dalam insititusi Mahkamah Agung.

Menurut Luhut M.P. Pangaribuan, keberadaan hakim ad hoc untuk mengatasi permasalahan yang ada dalam bagian reformasi kelembagan pengadilan antara lain (i) adanya penyalahgunaan wewenang, (ii) pelecehan hukum, (iii) pengabaian rasa keadilan, (iv) kurangnya perlindungan dan kepastian hukum bagi masyarakat. ${ }^{37}$ Apabila dihubungkan dengan konteks waktu diperkenalkannya, kehadiran hakim ad hoc adalah respon terhadap permasalahan aktuil yang sedang dihadapi lembaga pengadilan, antara lain rendahnya kepercayaan masyarakat terhadap institusi Pengadilan.

Pada awal pembentukannya, gagasan Hakim Ad hoc dalam memeriksa dan memutus perkara Tipikor dikarenakan 2 (dua) hal, Pertama adanya kebutuhan spesialisasi keahlian terutama di ilmu tentang tindak pidana korupsi dan hal lain yang terkait misalnya Pengadaan Barang, Keuangan dan Perbankan, dikarenakan Hakim karir dianggap tidak memiliki keahlian khusus tersebut. Kedua, adanya ketidakpercayaan terhadap Hakim karir, baik karena integritasnya atau independensinya dalam memeriksa dan memutus perkara terkait koleganya di internal Pengadilan. ${ }^{38}$ Kemandirian atau independensi Hakim Ad hoc dianggap pula lebih kuat dikarenakan tidak terikat pada birokrasi dan/atau sistem jenjang karir di

${ }^{36} \mathrm{KHN}$, "Penelitian Hakim Ad hoc dalam Pengadilan Niaga", tidak diterbitkan, Jakarta 20 Januari 2005, hal. 9.

\footnotetext{
${ }^{37}$ Luhut M.P Pangaribuan, Op. Cit., hal. 44.

${ }^{38}$ Rifqi S. Assegaff, dkk, Op. Cit, hal. 31.
} 
Pengadilan sehingga dapat membuatnya memeriksa dan memutus perkara dengan lebih baik. ${ }^{39}$

Hakim ad hoc dalam pengadilan Tindak Pidana Korupsi ini duduk sebagai hakim bersama hakim karir dalam suatu majelis yang bersifat kolegial sehingga mempunyai kedudukan yang sama dengan hakim karir ketika memeriksa, mengadili, dan memutus suatu perkara korupsi yang merupakan kewenangannya itu. Namun, hakim ad hoc yang ada pada pengadilan khusus pidana pada dasarnya adalah hakim biasa yang direkrut dari jalur non karir dan memiliki pengetahuan dan pengalaman di bidang hukum, sehingga penggunaan hakim ad hoc dalam pengadilan pidana Indonesia, salah satunya pengadilan tindak pidana korupsi, bukanlah merupakan lay participation dalam bentuk lay judges. ${ }^{40}$ Hal ini dikarenakan ketika hakim ad hoc diangkat akan sama juga seperti hakim karir yakni sebagai pejabat negara.

Hakim ad hoc yang mengadili perkara korupsi dalam pengadilan tipikor membawa common sense masyarakat yang ingin agar tegaknya hukum secara tegas dan tanpa pandang bulu dalam mengadili perkara korupsi. Kepercayaan masyarakat terdapat hakim ad hoc karena dalam track record hakim ad hoc memutus hukuman yang berat bagi para koruptor yang terbukti. Narendra Jatna berpendapat konsep ad hoc yang diterapkan di Indonesia telah mengalami kesalahan konsepsi. Menurutnya filosofi sistem ad-hoc yang sebenarnya yakni ad hoc adalah presentasi masyarakat/akses masyarakat atau biasa disebut lay judges. Sehingga orang yang mengisinya pun seharusnya masyarakat biasa seperti di negara Skandinavia yang menjadi hakim ad-hoc adalah mereka yang tidak mempunyai latar belakang hukum, tetapi mempunyai spesialisasi sendiri. $^{4}$

\section{c. Komposisi Hakim Ad hoc pada Pengadilan Tindak Pidana Korupsi}

Putusan Mahkamah Konstitusi Nomor 012-016-019/PUUIV/2006 pada tanggal 19 Desember 2006 mengamanatkan paling lama tiga tahun setelah putusan tersebut Pengadilan Tindak Pidana Korupsi harus sudah dibentuk berdasarkan undang-undang baru yang

${ }^{39}$ Reza Fikri Febriansyah, Mengadili Eksistensi Pengadilan Tindak Pidana Korupsi, dalam “Teropong”, (Depok: MaPPI FHUI, 2007), hal. 41.

${ }^{40}$ Lay judges adalah bentuk partisipasi di pengadilan yang dilakukan dalam bentuk kerjasama (kolaborasi) antaera hakim profesional (karir) dan non profesional (awam).

41 Narendra Jatna dalam Focus Group Discussion: Evaluasi Kinerja Pengadilan Tindak Pidana Korupsi, diselenggarakan oleh MaPPI FHUI di Hotel Morissey, Jakarta, 31 Agustus 2012. 
terpisah dari UU No. 30 Tahun 2002 tentang Komisi Pemberantasan Tindak Pidana Korupsi. Komposisi hakim dalam UU 46 Tahun 2009 Tentang Pengadilan Tipikor mengalami perubahan. Dalam UU Pengadilan Tipikor diatur bahwa komposisi hakim yang akan memeriksa perkara korupsi ditentukan oleh Ketua Pengadilan atau Ketua Mahkamah Agung sesuai dengan tingkatan dan kebutuhan setiap perkara yang disidangkan. Kewenangan tersebut berpengaruh pada jumlah hakim karena diberikan sepenuhnya kewenangan kepada Ketua Pengadilan Negeri untuk menentukan jumlah hakim yang menangani perkara korupsi. UU tersebut tidak mengatur secara tegas jumlah dan komposisi hakim seperti dalam Pasal 59 ayat (2) Undang-undang 30 Tahun 2002 Tentang Komisi Pemberantasan Korupsi yang mengatur 3 (tiga) hakim ad hoc dan 2 (dua) hakim karir. pengaturan mengenai komposisi hakim tersebut diatur dalam Pasal 26 UU Pengadilan Tipikor, yaitu: ${ }^{42}$

(1) Dalam memeriksa, mengadili, dan memutus perkara tindak pidana korupsi dilakukan dengan majelis hakim berjumlah ganjil sekurang-kurangnya 3 (tiga) orang hakim dan sebanyak-banyaknya 5 (lima) orang hakim, terdiri dari Hakim Karir dan Hakim ad hoc.

(2) Dalam hal majelis hakim sebagaimana dimaksud pada ayat (1) berjumlah 5 (lima) orang hakim, maka komposisi majelis hakim adalah 3 (tiga) banding 2 (dua) dan dalam hal majelis hakim berjumlah 3 (tiga) orang hakim, maka komposisi majelis hakim adalah 2 (dua) banding 1 (satu).

(3) Penentuan mengenai jumlah dan komposisi majelis hakim sebagaimana dimaksud pada ayat (1) dan ayat (2) ditetapkan oleh ketua pengadilan masing-masing atau Ketua Mahkamah Agung sesuai dengan tingkatan dan kepentingan pemeriksaan perkara kasus demi kasus.

Karakteristik komposisi Hakim ad hoc dalam menangani perkara di Pengadilan Tipikor menjadi sedikit berbeda dibandingkan dengan pengadilan khusus lainnya. Perbedaan tersebut membuat komposisi Hakim ad hoc tidak selamanya menjadi mayoritas (jumlah terbanyak) dalam memeriksa dan mengadili perkara di Pengadilan Tipikor.

\section{d. Rekrutmen Hakim Ad hoc Pengadilan Tindak Pidana Korupsi}

Hakim ad hoc pada Pengadilan Tindak Pidana Korupsi, pengadilan tinggi, dan pada Mahkamah Agung diangkat dan

\footnotetext{
${ }^{42}$ Indonesia, Undang-Undang Pengadilan Tindak Pidana Korupsi, Op.Cit., Pasal 26.
} 
diberhentikan oleh Presiden atas usul Ketua Mahkamah Agung. ${ }^{43}$ Hakim ad hoc diangkat untuk masa jabatan selama 5 (lima) tahun dan dapat diangkat kembali untuk 1 (satu) kali masa jabatan. ${ }^{44}$ Berdasarkan ketentuan ini pengangkatan dan pemberhentian Hakim ad hoc oleh Presiden bersifat meresmikan calon yang diusulkan oleh Ketua Mahkamah Agung. ${ }^{45}$

Pengangkatan sebagai Hakim ad hoc terdapat beberapa persyaratan. Calon Hakim ad hoc harus memenuhi persyaratan sebagai berikut: ${ }^{46}$

1. Warga negara Republik Indonesia;

2. Bertakwa kepada Tuhan Yang Maha Esa;

3. Sehat jasmani dan rohani;

4. Berpendidikan sarjana hukum atau sarjana lain dan berpengalaman di bidang hukum sekurang-kurangnya selama 15 (lima belas) tahun untuk hakim ad hoc pada pengadilan tindak pidana korupsi dan pengadilan tinggi, dan 20 (dua puluh) tahun untuk hakim ad hoc pada mahkamah agung;

5. Berumur sekurang-kurangnya 40 (empat puluh) tahun pada saat proses pemilihan untuk hakim ad hoc pada pengadilan tindak pidana korupsi dan pengadilan tinggi, dan 50 (lima puluh) tahun untuk hakim ad hoc pada mahkamah agung;

6. Tidak pernah dipidana karena melakukan kejahatan berdasarkan putusan pengadilan yang telah memperoleh kekuatan hukum tetap;

7. Jujur, adil, cakap, dan memiliki integritas moral yang tinggi serta reputasi yang baik;

8. Tidak menjadi pengurus dan anggota partai politik;

9. Melaporkan harta kekayaannya;

10. Bersedia mengikuti pelatihan sebagai hakim tindak pidana korupsi; dan

11. Bersedia melepaskan jabatan struktural dan/atau jabatan lain selama menjadi hakim ad hoc tindak pidana korupsi.

12. Bersedia ditempatkan di seluruh wilayah Indonesia;

13. Izin tertulis dari atasan langsung/atasan yang berwenang bagi pelamar yang berstatus pegawai negeri sipil; dan

\footnotetext{
${ }^{43}$ Indonesia, Ibid., Pasal 10 ayat (4).

${ }^{44}$ Ibid., Pasal 10 ayat (5).

${ }^{45}$ Ibid., Penjelasan Pasal 10 Ayat (4).

${ }^{46}$ Ibid., Pasal 12 jo Pasal 4.
} 
14. Bersedia mengganti biaya seleksi dan pelatihan apabila mengundurkan dini sebagai hakim ad hoc sebesar nilai yang diterapkan oleh panitia.

Persyaratan hakim ad hoc dapat berasal dari "sarjana lainnya" atau sarjana selain sarjana hukum. Timbul kekhawatiran dan perdebatan, apakah seorang sarjana non-hukum ini dapat menguasai hukum acara pidana, karena selain hukum pidana meteriil yang harus dikuasai oleh para hakim juga mengenai pidana formil untuk mengungkap kebenaran materiilnya. Oleh karena itu untuk mengantisipasi hal tersebut, Hakim Ad hoc yang terpilih berdasarkan Pasal 12 huruf (J) UU Pengadilan Tindak Pidana Korupsi diwajibkan untuk mengikuti pelatihan hakim yang diberikan oleh Mahkamah Agung.

Proses pemilihan dan pengusulan calon Hakim ad hoc pada Pengadilan Tindak Pidana Korupsi dan pengadilan tinggi, Ketua Mahkamah Agung membentuk panitia seleksi yang terdiri dari unsur Mahkamah Agung dan masyarakat yang dalam menjalankan tugasnya bersifat mandiri dan transparan. ${ }^{47}$ Ketentuan mengenai tata cara pemilihan untuk diusulkan sebagai Hakim ad hoc diatur dengan Peraturan Mahkamah Agung. ${ }^{48}$

Tahapan penyelenggaraan seleksi ${ }^{49}$ calon Hakim Ad hoc terdiri atas seleksi administrasi, tes tertulis dan seleksi kompetensi.

a) Seleksi Administrasi ${ }^{50}$

Seleksi administrasi adalah seleksi yang berkaitan dengan data/identitas dan kelengkapan administrasi yang dipersyaratkan bagi para calon Hakim Ad hoc Seleksi Administrasi diawali dengan pengumuman pembukaan lamaran calon Hakim Ad hoc secara terbuka sehingga dapat diketahui oleh khalayak umum dengan mencantumkan secara jelas syarat-syarat serta tata cara pembuatan dan penyampaian lamaran. ${ }^{51}$

b) Tes tertulis

${ }^{47}$ Ibid., Pasal 13 ayat 1.

${ }^{48}$ Ibid., Pasal 13 ayat 2.

49 Vide Pasal 1 ayat 4, disebutkan bahwa seleksi adalah rangkaian kegiatan yang dilaksanakan secara bertahap untuk memilih calon Hakim Ad hoc yang memenuhi syarat untuk dapat diikutsertakan dalam pelatihan.

${ }^{50}$ Mahkamah Agung, Peraturan Mahkamah Agung tentang Pedoman Penyelenggaraan Seleksi Calon Hakim Ad hoc Pada Pengadilan Tindak Pidana Korupsi, Pengadilan Tinggi, dan Mahkamah Agung, Perma No, 4 tahun 2009, Pasal 1 angka 5.

${ }^{51}$ Ibid., Pasal 3. 
Tes tertulis adalah ujian secara tertulis yang diberikan kepada para calon Hakim Ad hoc untuk menguji penguasaan tentang pengetahuan di bidang Hukum Acara dan Hukum Materiil yang berhubungan dengan tindak pidana korupsi. ${ }^{52}$ Materi tes tertulis terdiri atas: ${ }^{53}$

a. Psikotes;

b. Materi yang menyangkut tindak pidana korupsi;

c. Hukum Acara Pidana dan Teknis Peradilan.

c) Seleksi Kompetensi

Seleksi kompetensi adalah seleksi yang berkaitan dengan kondisi mental dan kepribadian serta wawancara terhadap para calon Hakim Ad hoc yang dapat menunjang profesionalitas pelaksanaan tugas. ${ }^{54}$ Pengaturan mengenai seleksi kompetensi, ${ }^{55}$ yaitu:

1) Seleksi kompetensi terdiri atas:

a. penilaian kondisi mental dan kepribadian (profile assessment) para calon Hakim Ad hoc yang dapat menunjang profesionalitas pelaksanaan tugas;

b. penilaian kemampuan verbal serta pengamatan penampilan, sikap, dan perilaku para calon Hakim Ad hoc.

Penilaian kondisi mental dan kepribadian (profile assessment) dilaksanakan oleh tim psikologi dan dilaporkan kepada panitia. Wawancara dilaksanakan oleh Tim Pewawancara. Calon Hakim Ad hoc dinyatakan lulus seleksi kompetensi setelah ditentukan dalam rapat panitia yang dituangkan dalam berita acara dan keputusan panitia tidak dapat diganggu gugat. Peserta yang dinyatakan lulus seleksi kompetensi wajib mengikuti pelatihan calon Hakim Ad hoc. Calon Hakim Ad hoc diwajibkan mengikuti tahapan penyelenggaraan seleksi.

\section{Kebutuhan Hakim Pengadilan Tindak Pidana Korupsi}

Pengesahan UU Pengadilan Tipikor yang mengatur pembentukan Pengadilan Tipikor di 33 Provinisi telah mengharuskan MA untuk merekrut Hakim ad hoc baru untuk mengisi kekosongan hakim yang dibutuhkan. Pada tahun 2010, MA meloloskan 108 hakim ad hoc, 30

\footnotetext{
${ }^{52}$ Indonesia, Undang-Undang Pengadilan Tindak Pidana Korupsi, Op. Cit., Pasal 1 ayat 6.

${ }^{53}$ Mahkamah Agung, Perma N0. 4 Tahun 2009, Op. Cit., Pasal 8.

${ }^{54}$ Indonesia, Undang-Undang Pengadilan Tindak Pidana Korupsi, Op. Cit., Pasal 1 ayat 8.

${ }^{55}$ Mahkamah Agung, Perma N0. 4 Tahun 2009, Op. Cit., Pasal 12.
} 
orang hakim ditugaskan untuk menjadi hakim ad hoc tingkat banding, 74 orang untuk tingkat pertama dan 4 orang di tingkat kasasi. Pada 2011, hakim ad hoc tingkat pertama sebanyak 30 orang dan tingkat banding sebanyak 54 orang.

Berdasarkan Laporan akhir tahun Mahkamah Agung pada tahun 2011 terdapat 250 hakim karir yang ditugaskan pada Pengadilan Tindak Pidana Korupsi dan ada 128 Hakim Ad hoc yang ditugaskan di Pengadilan Ad hoc di seluruh Indonesia. ${ }^{56}$ Jumlah ini masih jauh dari memadai sehingga MA menargetkan akan merekrut 96 Hakim Ad hoc Tipikor baru pada tahun 2012 karena berdasarkan UU No. 46 Tahun 2009 tentang Pengadilan Tindak Pidana Korupsi perlu dibentuk Pengadilan di setiap Kotamadya untuk Daerah Khusus Ibukota (Jakarta), sehingga Pengadilan Tindak Pidana Korupsi yang saat ini hanya berada di Jakarta Pusat akan ditambah di Kotamadya lainnya. ${ }^{57}$ Penambahan jumlah pengadilan khusus ini berimbas pada kebutuhan hakim yang akan bertugas nanti.

Selain kendala jumlah, beberapa kendala lainnya terkait kualitas hakim ad hoc pada Pengadilan Tindak Pidana korupsi diantaranya kualitas dalam membuat putusan. Apabila dibandingkan dengan hakim karir yang bertahun-tahun membuat putusan jelas akan berbeda kualitasnya. Hakim Ad hoc pada Pengadilan Tipikor selain di Jakarta berkisar 1 hingga 2 tahun penglaman menjadi hakim, sehingga ada kekurangan dalam membuat putusan. Menurut Djoko Sarwoko sekitar $60 \%$ dari hakim ad hoc berprofesi sebagai Advokat. Kualitas hakim ad hoc yang bertugas di pengadilan khusus ini juga menjadi sorotan Yudi Kristiana, Jaksa pada KPK. Menurut Yudi, terdapat perbedaan kualitas terutama dalam teknis menyidangkan suatu perkara. Pertanyaanpertanyaan yang diajukan oleh Hakim Ad hoc terkadang intimidatif, melemahkan saksi yang diajukan JPU, dan kurang dapat menggali kesaksian untuk mendapatkan kebenaran materiil. Beberapa putusan perkara korupsi yang dibebaskan juga dibuat oleh hakim Ad hoc.

Permasalahan ini sedang diatasi oleh Mahkamah Agung dengan melakukan pelatihan bagi Hakim pada Pengadilan Tipikor. Berdasarkan laporan tahunan Mahkamah Agung tahun 2011, Mahkamah Agung melakukan pelatihan bagi 122 Hakim yang terdiri dari 80 hakim pada tingkat pertama dan 40 hakim pada tingkat banding. ${ }^{58}$ Pelatihan dengan materi Hukum Acara Pidana Korupsi, ${ }^{59}$ Tindak Pidana Pencucian Uang

\footnotetext{
${ }^{56}$ Mahkamah Agung Republik Indonesia, "Laporan Tahunan 2011”, (Jakarta: MA RI, 2012), hal. 74

${ }^{57}$ Kompas, MA Tambah 4 Pengadilan Tipikor, Rabu 13 Juni 2012.

${ }^{58}$ Mahkamah Agung Republik Indonesia, Op. Cit., hal. 72.

59 <http://news.okezone.com/read/2011/11/14/339/529371/ma-tatar-hakim-ad-hoctipikor>, diakses 24 Juli 2012.
} 
bekerja sama dengan Pusat Pelaporan Analisa Transaksi Keuangan (PPATK), pemidanaan, sifat melawan hukum. ${ }^{60}$ Komisi Yudisial seharusnya juga dapat berperan lebih dalam memberikan materi pelatihan kepada para hakim Ad hoc tersebut. Komisi Yudisial di New South Wales, sebagai contoh, yang tidak hanya fokus pada pengawasan hakim tetapi juga meningkatkan kualitas dan kapasitas hakim melalui Continuing Education (Pendidikan Berkelanjutan). ${ }^{61}$ Kegiatan ini bertujuan untuk mendorong peningkatan performa pengadilan dengan memberikan materi terkait hukum, keadilan, dan hal lain yang berkaitan kepada hakim; serta membantu dalam pengembangan keahlian khusus dan nilai-nilai yang penting dimiliki oleh seorang hakim. ${ }^{62}$ Hal ini yang disebut oleh Firmansyah Arifin, Tenaga Ahli KY, proses pembinaan berkala dengan memberikan materi hukum yang berkembang terkait kasus korupsi dan yang berkaitan. ${ }^{63}$

Paska disahkannya UU No. 46 Tahun 2009 Tentang Pengadilan Tindak Pidana Korupsi, rekrutmen hakim ad hoc ternyata hanya mengejar terpenuhinya kuantitas yang dibutuhkan, tetapi tidak secara kualitas. Anggota Tim Pembaharuan Mahkamah Agung, Desita Sari, membenarkan bahwa Mahkamah Agung memang mengejar terpenuhinya kuantitas hakim ad hoc tipikor yang dibutuhkan di tiap Provinsi. ${ }^{64}$ Mahkamah Agung memang diperintahkan oleh UU Pengadilan Tipikor untuk membentuk Pengadilan di tiap Provinsi, sehingga agar dapat berjalannya diperlukan Sumber daya manusianya termasuk hakim ad hoc Tipikor.

Semangat awal pembentukan Pengadilan Tindak Pidana Korupsi dengan terdapat kekhususan hakim ad hoc yang memeriksa adalah untuk mengembalikan kredibilitas institusi Pengadilan sehingga dapat memeriksa dan memutus perkara Tipikor dengan baik. Pada kenyataannya harapan tersebut belum terealisasi, paling tidak berdasarkan jajak pendapat Kompas pada tahun 2011. Jajak Pendapat yang dilakukan oleh Kompas beberapa pekan setelah Pengadilan Tipikor Samarinda, awal Oktober 2011, dalam empat hari berturut-turut menjatuhkan vonis bebas terhadap 14 terdakwa koruptor. Pengadilan Tipikor Surabaya selama 2011 menjatuhkan putusan bebas untuk 22

\footnotetext{
${ }^{60}$ Wawancara Djoko Sarwoko 28 Juni 2012.

61 <http://www.judcom.nsw.gov.au/>, diakses 28 Agustus 2012.

62 <http://www.judcom.nsw.gov.au/education/education>, diakses 28 Agustus 2012.

${ }^{63}$ Wawancara Firmansya Arifin, 14 Agustus 2012.

${ }^{64}$ Desita Sari dalam Focus Group Discussion: Evaluasi Kinerja Pengadilan Tindak Pidana Korupsi, diselenggarakan oleh MaPPI FHUI di Hotel Morissey, Jakarta, 31 Agustus
} 2012. 
perkara korupsi. Pengadilan Tipikor Bandung tiga kali membuat putusan bebas dalam kasus korupsi yang melibatkan kepala daerah. ${ }^{65}$

Jajak Pendapat Kompas dilakukan pada tahun 2011, selang 2 (dua) tahun setelah UU No. 46 Tahun 2009 Tentang Pengadilan Tipikor disahkan. Dalam kurun waktu tersebut ternyata penilaian publik terhadap kinerja pengadilan, termasuk di dalamnya hakim, dalam mengadili perkara Tipikor masih jauh dibawah ekspektasi masyarakat. Sebanyak 91,7\% masyarakat yang tidak puas dengan kinerja hakim dalam mememutuskan perkara korupsi yang menyangkut Pejabat Negara. Masyarakat 95,2\% tidak mempercayai bahwa hakim tersebut dalam memutus telah bebas dari intervensi lain diluar kekuasaan kehakiman. Penilaian masyarakat terhadap hakim dan pengadilan dalam menyidangkan dan memutus perkara-perkara korupsi belum beranjak membaik meski Pengadilan Tindak pidana Korupsi telah didirikan. Menurut data ICW Pengadilan Tipikor di daerah yang dibentuk paska UU No. 46 Tahun 2009 Tentang Pengadilan Tipikor hingga awal 2012 telah membebaskan 66 terdakwa korupsi. Berikut Tabel Pengadilan Tipikor yang sering membebaskan terdakwa korupsi di Daerah. ${ }^{66}$

Tabel Pengadilan Tipikor Daerah

\begin{tabular}{|c|c|c|c|c|c|c|c|c|}
\hline $\begin{array}{c}\text { Pengadil } \\
\text { an }\end{array}$ & $\begin{array}{c}\text { Sema } \\
\text { rang }\end{array}$ & $\begin{array}{c}\text { Sura } \\
\text { baya }\end{array}$ & Samarinda & Makasar & $\begin{array}{c}\text { Bandu } \\
\text { ng }\end{array}$ & $\begin{array}{c}\text { Palem } \\
\text { bang }\end{array}$ & Serang & $\begin{array}{c}\text { Banjar } \\
\text { masin }\end{array}$ \\
\hline $\begin{array}{c}\text { Jumlah } \\
\text { Terdakw } \\
\text { a Bebas }\end{array}$ & 3 & 26 & 19 & 4 & 6 & 1 & 1 & 1 \\
\hline
\end{tabular}

Hal ini terjadi karena kurangnya kemampuan teknis dan integritas hakim yang menyidangkan, termasuk hakim ad hoc. Rekrutmen hakim ad hoc menjadi suatu permasalahan yang perlu ditangani secara serius oleh Mahkamah Agung. Rekrutmen hakim ad hoc yang dilakukan untuk memenuhi kuota hakim paska diberlakukannya UU No. 46 Tahun 2009 tentang Pengadilan Tindak Pidana Korupsi belum dapat menyaring orang-orang terbaik untuk menjadi hakim. Hakim ad hoc yang bertugas di pengadilan tindak pidana korupsi pada umumnya (sekitar 60\%) memiliki latar belakang sebagai advokat. Perubahan peran dari seorang pembela menjadi seorang pemutus tentunya tidak dapat dengan mudah dilakukan, terlebih lagi bila semangat membela klien yang dimiliki oleh para mantan advokat ini masih mendominasi pelaksanaan tugas mereka.

${ }^{65}$ Kompas, Benteng Terakhir Semakin Lapuk, 14 November 2011.

${ }^{66}$ Surat Koalisi Pemantau Peradilan kepada Ketua Mahkamah Agung RI, tertanggal 11 Mei 2012. 
Salah satu hakim ad hoc yang direkrut oleh MA adalah Ramlan Comel. Ramlan Comel sebelumnya berprofesi sebagai advokat dan pernah menjadi terdakwa kasus korupsi dana overhead di perusahaan PT Bumi Siak Pusako sebesar US\$ 194.496 atau setara dengan Rp 1,8 miliar. Dalam kasus tersebut, Pengadilan Negeri Pekan Baru menjatuhkan vonis selama 2 tahun penjara. Namun pada tingkat banding di Pengadilan Tinggi Riau pada tahun 2005, Ramlan Comel dinyatakan bebas. Putusan Pengadilan Tinggi tersebut diperkuat oleh Mahkamah Agung pada tingkat kasasi tahun 2006 (Putusan Nomor 153K/PID/2006). Ramlan Comel tercatat pernah membebaskan 2 (dua) orang terdakwa yakni Eep Hidayat (Bupati Subang), dan Mochtar Mohammad (Walikota Bekasi). ${ }^{67}$

Hakim Ad hoc yang direkrut bersamaan dengan Ramlan Comel, Kartini Marpaung dan Heru Kusbandono, tertangkap tangan sedang menerima suap untuk menangani perkara Ketua DPRD Grobogan Muhammad Yaeni. Keduanya ditangkap pada tanggal 17 Agustus 2012 di Pengadilan Negeri Semarang. Hakim tersebut sebelumnya bekerja sebagai advokat. ${ }^{68}$ Penangkapan ini membuat kepercayaan masyarakat terhadap hakim ad hoc yang awalnya dinilai bersih dan berintegritas menjadi menurun.

Mahkamah Agung dalam proses perekrutan tahap pertama memang melibatkan unsur masyarakat. Namun pelibatan unsur masyarakat dalam rekrutmen hakim ad hoc juga tidak dilakukan secara rutin oleh MA karena keterbatasan anggaran. Rekrutmen hakim ad hoc tahap pertama sampai tahap ketiga tidak melibatkan Komisi Yudisial. Perihal tidak adanya keterlibatan Komisi Yudisial ini karena pada undang-undang tentang Pengadilan Tindak Pidana Korupsi tidak mengaturnya. Namun, keikutsertaan Komisi Yudisial sekiranya dapat membantu MA dalam proses rekrutmen tersebut. Meskipun demikian Komisi Yudisial hanya dilibatkan dalam sertifikasi hakim karir Tipikor. Proses tersebut sudah berjalan sejak tahun 2007, namun dalam kurun 1-2 tahun terakhir Komisi Yudisial tidak lagi dilibatkan. ${ }^{69}$

Kritik keras terhadap Hakim Ad hoc juga dilontarkan oleh Binsar M. Gultom, Hakim di PN Bengkulu dalam bukunya "Pandangan Kritis Seorang Hakim dalam Penegakan Hukum di Indonesia". Menurut Binsar keberadaan Hakim Ad hoc yang berasal dari jalur non-karir mengakibatkan sedikitnya 3 (tiga) kerugian:

a. Merusak Sistem Rekrutmen Calon Hakim hingga Hakim Agung Proses perekrutan calon hakim (cakim) yang berasal dari jalur karir memiliki tahapan yang terstruktur secara sistematis lewat

\footnotetext{
${ }^{67}$ Ibid.

${ }^{68}$ Majalah Tempo, 16-22 September 2012, hal. 88.

${ }^{69}$ Wawancara Firmansyah Arifin, 14Agustus 2012.
} 
pendidikan dan pelatihan cakim beberapa tahun, magang di beberapa Pengadilan tingkat pertama selama 3-4 tahun hingga diangkat menjadi hakim. Proses ini yang membuat kemampuan dan keahlian seeseorang sebagai hakim terasah.

b. Menyudutkan Posisi Hakim Karir

Penilaian bahwa hakim Ad hoc lebih berintegritas dan lebih baik secara kemampuan pada kenyataannya seringkali tidak terbukti.

c. Pemborosan Uang Negara

Hakim Ad hoc tetap mendapatkan gaji dan tunjangan meskipun tidak ada perkara yang dilimpahkan kepada Pengadilan khusus (Tipikor). Hal ini yang membuat Anggara Negara menjadi terkuras. $^{70}$

Pendapat Binsar tersebut senada dengan pemikiran Luhut M.P. Pangaribuan yang menilai bahwa apabila keahlian khusus yang diperlukan untuk menjernihkan suatu perkara dapat saja Pengadilan mendatangkan ahli untuk mendengarkan keterangannya. Hal ini dalam praktiknya akan lebih efisien dan efektif dari pada melakukan seleksi dan mendudukan hakim Ad hoc dalam Pengadilan. ${ }^{71}$ Sedangkan Narendra berpendapat kalaupun tetap ingin dipertahankan hakim ad hoc sebaiknya seperti konsep yang ada di Skandinavia. Hakim ad hoc yang merupakan representasi masyarakat dengan keahlian tertentu tersebut, direkrut dan diberi honor apabila ada persidangan tindak pidana korupsi, tidak diangkat dan diberikan gaji secara bulanan beserta tunjangan yang akan menguras anggaran Negara. ${ }^{72}$

Sistem perekrutan, pengawasan, hingga anggaran bagi hakim Tipikor (Karir atau Ad hoc) telah dipikirkan oleh Peneliti LeIP sebelum disahkannya UU No. 46 Tahun 2009 Tentang Pengadilan Tindak Pidana Korupsi. Bertambahnya Pengadilan Tindak Pidana Korupsi di tiap Ibukota Provinsi (Konsep RUU awal Tiap Kabupaten/Kota) akan mengakibatkan berbagai permasalahan sehingga sebaiknya hanya ada di Ibukota Jakarta atau 5 (lima) wilayah seperti Jakarta, Medan, Makasar, Surabaya, dan Kalimantan. Salah satu yang menjadi perhatian adalah minat calon hakim Ad hoc. Berdasarkan sejarahnya, pada perekrutan Hakim Ad hoc tahap pertama (2004-2005) dari target 9 hakim Ad hoc, hanya berhasil direkrut 3 orang dan itu pun terpaksa Panitia Seleksi menurunkan standard penilaiannya. Beberapa faktor yang menyebabkan keengganan untuk mendaftar sebagai hakim Ad hoc Tipikor diantaranya

\footnotetext{
${ }^{70}$ Binsar M. Gultom, "Pandangan Kritis Seorang Hakin dalam Penegakan Hukum di Inadonesia”, (Jakarta: PT Gramedia Pustaka Utama, 2012), hal. 75.

${ }^{71}$ Luhut M.P. Pangaribuan, Op. Cit., hal. 493.

${ }^{72}$ Narendra Jatna, Ibid.
} 
(i) Pendapatan yang kecil; (ii) Ketidakpastian karir, karena hanya menjabat untuk 2 periode (10 tahun); (iii) jabatan tersebut tidak memiliki prestise yang cukup memadai dan; (iv) Kurang terjaminnya keamanan hakim mengingat banyak kasus terkait orang yang memiliki kekuatan secara politik atau ekonomi. ${ }^{73}$

Terkait dengan kedudukan seorang hakim ad hoc, Menteri Pendayagunaan Aparatur Negara (Menpan) telah mengeluarkan surat bernomor B/1422/M.PAN-RB/6/2010 tertanggal 21 Juni 2010 yang secara tegas menyebutkan bahwa hakim ad hoc pengadilan tipikor bukanlah pejabat negara. Surat tersebut mendasarkan pada Pasal 11 Ayat (1) UU No. 43 Tahun 1999 tentang Pokok-pokok Kepegawaian, UU No. 46 Tahun 2009 tentang Pengadilan Tipikor, UU No. 48 Tahun 2009 tentang Kekuasaan Kehakiman yang tidak mengatur secara eksplisit bahwa hakim ad hoc adalah bukan pejabat negara. Berdasarkan surat tersebut status hakim Ad hoc menjadi berbeda dengan hakim karir lainnya. ${ }^{74}$ Konsekuensinya seorang hakim Ad hoc yang tidak ditetapkan sebagai Pejabat Negara secara materil adalah beberapa pendapatan yang berkurang dikarenakan tidak dapat Gaji ke-13 dan adanya potongan PPH 21 terhadap tunjangannya karena tidak dibayarkan oleh Negara dan tunjangan lain yang didapatkan seorang Pejabat Negara berdasarkan Peraturan Pemerintah (PP) Nomor 41 Tahun 2002 tentang Pejabat Negara. Salah satu dampaknya dengan dikeluarkannya Surat Dirjen Perbendaharaan Kementerian Keuangan RI Direktorat Jenderal Perbendaharaan Nomor S-6519/PB/2011 perihal Pemotongan Pajak Penghasilan $(\mathrm{PPh})$ Pasal 21 Uang Kehormatan atau Tunjangan bagi Hakim Ad hoc,

Jika dibaca lebih teliti lagi Pasal 19 UU Kekuasaan Kehakiman yaitu, "Hakim dan hakim konstitusi adalah pejabat negara yang melakukan kekuasaan kehakiman yang diatur dalam undang undang." Memang tidak secara eksplisit dijelaskan, namun kita perlu mengetahui apa yang dimaksud "hakim" pada UU Kekuasaan Kehakiman tersebut.

Istilah hakim yang digunakan dalam UU tersebut merujuk pada suatu pengertian:

Hakim adalah hakim pada Mahkamah Agung dan hakim pada badan peradilan yang berada di bawahnya dalam lingkungan peradilan umum, lingkungan peradilan agama, lingkungan peradilan militer, lingkungan peradilan tata usaha negara, dan hakim pada pengadilan khusus yang berada dalam lingkungan peradilan tersebut. $^{75}$

\footnotetext{
${ }^{73}$ Wawancara Arsil tanggal 25 Juli 2012.

74 <http://www.hukumonline.com/berita/baca/lt4dfde434e4dd6/pemerintah-tegaskanhakim-iad-hoci-bukan-pejabat>, diakses 28 Agustus 2012.
} 
Hakim Ad hoc tipikor merupakan hakim pada Pengadilan Khusus, yaitu Pengadilan Tipikor yang dibentuk berdasarkan UU Mo. 46 tahun 2009 tentang Tipikor. Hakim Ad hoc tipikor juga sebagai pelaksana inti fungsional dalam melakukan kekuasaan kehakiman di Pengadilan khusus Tipikor tersebut. Hakim Ad hoc memiliki kewenangan yang sama untuk memeriksa, menyidangkan, hingga memutus perkara-perkara Tipikor. Selayaknya status dan kedudukan hakim Ad hoc disamakan sebagai Pejabat Negara karena jika ditinjau lebih teliti dari kedua UU tersebut maka hakim Ad hoc juga berstatus Pejabat Negara. Hal tersebut sudah diputuskan oleh Pengadilan TUN Palembang. Dalam putusan Putusan Nomor: 49/G/2011/PTUN-PLG menyatakan Surat Permasalahan terkait dengan keberadaan pengadilan tindak pidana korupsi dan hakim ad hoc menunjukkan bahwa upaya pemberantasan korupsi belum direncanakan dengan baik dan lebih terkesan sporadis untuk kebutuhan politik sesaat. Pada sisi lain, pembentukan pengadilan tindak pidana korupsi yang tidak terencana ini justru menjadikan peluang bagi pihak-pihak yang pro terhadap tindak pidana korupsi untuk menggagalkan upaya-upaya pemberantasannya. Salah satunya adalah dengan mensyaratkan adanya hakim ad hoc di setiap pengadilan yang tersebar di seluruh Indonesia.

\section{Pengadilan Tindak Pidana Korupsi dalam Pantauan}

Berikut ini adalah hasil pengamatan dan pemantauan Pengadilan Tindak Pidana Korupsi di Bandung dan Jakarta. Pengamatan dilakukan tidak hanya terhadap hakim, melainkan juga terhadap sarana dan prasarana pendukung kinerja pengadilan tindak pidana korupsi.

\section{a. Pengadilan Tipikor Bandung}

Hakim pada Pengadilan Tipikor Bandung terdiri dari 10 hakim karir (termasuk Ketua dan Wakil Ketua Pengadilan Negeri Bandung) dan 6 hakim ad hoc Tipikor. Keseluruhan hakim ad hoc Tipikor yang bertugas di PN Bandung sebelumnya berprofesi sebagai Pengacara.

Dari 106 perkara yang disidangkan pada awal terbentuknya yaitu tahun 2011, terdapat perbedaan data perkara yang diputus. Berdasarkan Rekapitulasi Pengadilan Negeri bandung sebanyak 105 perkara yang putus, namun menurut Badan Peradilan Umum Mahkamah Agung (Badilum MA) sebanyak 61 perkara yang putus. Dari data Pengadilan Negeri Bandung, terdapat 11 perkara yang diputus bebas. Atau sekitar $9.6 \%$ perkara yang dibebaskan.

Dua dari putusan bebas tersebut, yaitu putusan Mochtar Muhammad (Walikota Bekasi) dan Eep Hidayat (Bupati Subang) 
sudah diputus kasasi oleh Mahkamah Agung. Keduanya terbukti bersalah melakukan tindak pidana korupsi dan dijatuhi hukuman masing-masing enam dan lima tahun penjara. ${ }^{76}$

Dari jumlah perkara tersebut, rata-rata 8.8 kasus tipikor yang ditangani dalam 1 bulan. Dari jumlah tersebut dapat diperkirakan hakim karir menyidangkan 1 perkara Tipikor tiap bulannya apabila terdapat 1 hakim karir dalam Majelis, atau 2 perkara Tipikor tiap bulannya apabila terdapat 2 hakim dalam Majelis. Beban penanganan perkara tersebut juga tidak jauh berbeda dialami oleh hakim ad hoc Tipikor.

Namun terdapat perbedaan yang mencolok apabila dilihat dari keseluruhan beban penanganan perkara antara hakim ad hoc dan karir. Hakim karir dalam UU Pengadilan Tipikor diatur tidak diperkenankan untuk menyidangkan perkara lain (umum), namun dalam praktiknya di Pengadilan Tipikor Bandung, hakim karir masih menyidangkan perkara pidana umum. Hal ini dikarenakan perkara yang masuk ke Pengadilan cukup banyak.

Keadaan ini menyebabkan perbedaan beban penanganan perkara yang cukup signifikan dan berpotensi timbul kesenjangan. Hakim ad hoc dan karir memiliki gaji dan tunjangan yang besarannya hampir sama, namun jumlah pekerjaannya berbeda cukup jauh. Berdasarkan wawancara dengan Ketua Pengadilan Negeri Bandung dan Panitera Muda Pengadilan Tipikor Bandung, Hakim ad hoc seringkali tidak datang ke Pengadilan di hari-hari tertentu apabila tidak ada sidang. Namun, Hal itu diatasi oleh Ketua Pengadilan dengan mengeluarkan himbauan untuk tetap hadir meski tidak ada sidang. Ketidakhadiran hakim ad hoc selain menimbulkan potensi kesenjangan, juga membuka peluang hakim ad hoc tersebut masih menjalankan kantor hukum tempat ia berprofesi dulu. Beberapa temuan ICW dan berdasarkan wawancara dengan pihak Pengadilan Negeri Bandung menyatakan hal tersebut. ${ }^{77}$ Seorang hakim ad hoc Tipikor di Aceh tercatat masih membuka kantor hukumnya di daerah Medan. Tiap hari Jumat, hakim tersebut kembali ke Medan untuk menjalankan kantor hukumnya. Hakim tersebut juga masih menangani beberapa perkara sebagai advokat di Medan. ${ }^{78}$ Hal ini jelas melanggar Pasal 15 huruf (c) UU Pengadilan Tipikor, bahwa seorang hakim ad hoc dilarang merangkap jabatan sebagai Advokat.

\footnotetext{
76 <http://www.republika.co.id/berita/nasional/umum/12/03/20/m16bgo-dpr-berharapputusan-ma-bukan-pencitraan>, diakses 11 September 2012.

77 <http://www.seputar-indonesia.com/edisicetak/content/view/522455/>, diakses 11 September 2012.

${ }^{78}$ Majalah Tempo, edisi 10-16 September 2012, hal. 81.
} 
Komposisi hakim yang menyidangkan perkara Tipikor di Pengadilan Tipikor Bandung menurut wawancara KPN Bandung terdiri dari mayoritas hakim ad hoc namun majelis tetap diketuai oleh hakim karir. Keadaan ini ditujukan agar hakim ad hoc dapat cepat beradaptasi dan mempelajari hal-hal yang diperlukan untuk menjadi seorang hakim. Pemberian jam terbang dengan menyidangkan perkara Tipikor akan mempercepat pembelajaran kepada hakim ad hoc. ${ }^{79}$

\section{b. Pengadilan Tipikor Jakarta}

Pengadilan Tipikor Jakarta merupakan yang pertama kali didirikan sejak tahun 2004 berdasarkan Keputusan Presiden Republik Indonesia Nomor 59 Tahun 2004 Tentang Pembentukan Pengadilan Tindak Pidana Korupsi Pada Pengadilan Negeri Jakarta Pusat. Kiprah dan kinerja Pengadilan ini diapresiasi publik seperti telah diutarakan pada pembahasan selanjutnya. Hingga saat ini Pengadilan Tipikor Jakarta belum pernah membebaskan terdakwanya.

Kondisi tersebut sebenarnya tidak mutlak dikarenakan oleh hakim yang menyidangkannya. Misalnya, pada awal Pengadilan Tipikor di Jakarta dibentuk seluruh penuntutannya dilakukan oleh Komisi Pemberantasan Korupsi, sedangkan Jaksa dari Kejaksaan penuntutan dilakukan di Pengadilan Negeri setempat. Faktor baiknya dakwaan, pembuktian, dan tuntutan yang dilakukan oleh KPK bisa saja menjadi faktor yang dominan. Selain itu, euforia Pengadilan Tipikor yang pertama kali di Jakarta mendapatkan perhatian publik dan pers yang cukup tinggi. Sehingga kontrol langsung dari masyarakat dan pers terhadap jalannya persidangan di Pengadilan Tipikor Jakarta juga semakin tinggi.

\section{Tabel 2}

\section{Perkara Tipikor 2004-2012 (Berdasarkan Buku Register PN Jakarta Pusat)}

\footnotetext{
${ }^{79}$ Wawancara Singgih Budi Prakoso, SH, MH, Kamis, 6 September 2012.
} 


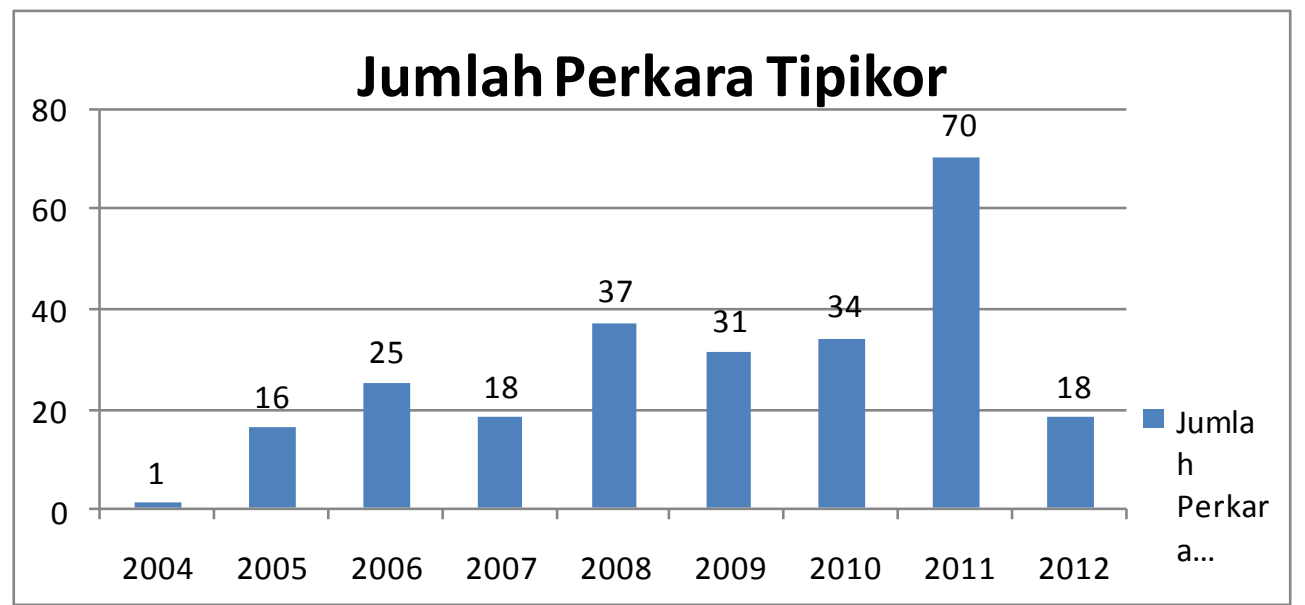

Jika melihat tabel diatas, peningkatan penanganan kasus korupsi terjadi pada tahun 2011, terjadi penambahan 36 perkara atau setara dengan dua kali lipat dari perkara tahun sebelumna. Hal ini terjadi karena mulai tahun 2010 perkara yang masuk di Pengadilan Tipikor Jakarta tidak hanya yang dituntut oleh KPK tetapi juga Kejaksaan.

Tabel 3

Data perkara Tipikor di Pengadilan Tipikor Jakarta 2010-2011 ${ }^{80}$

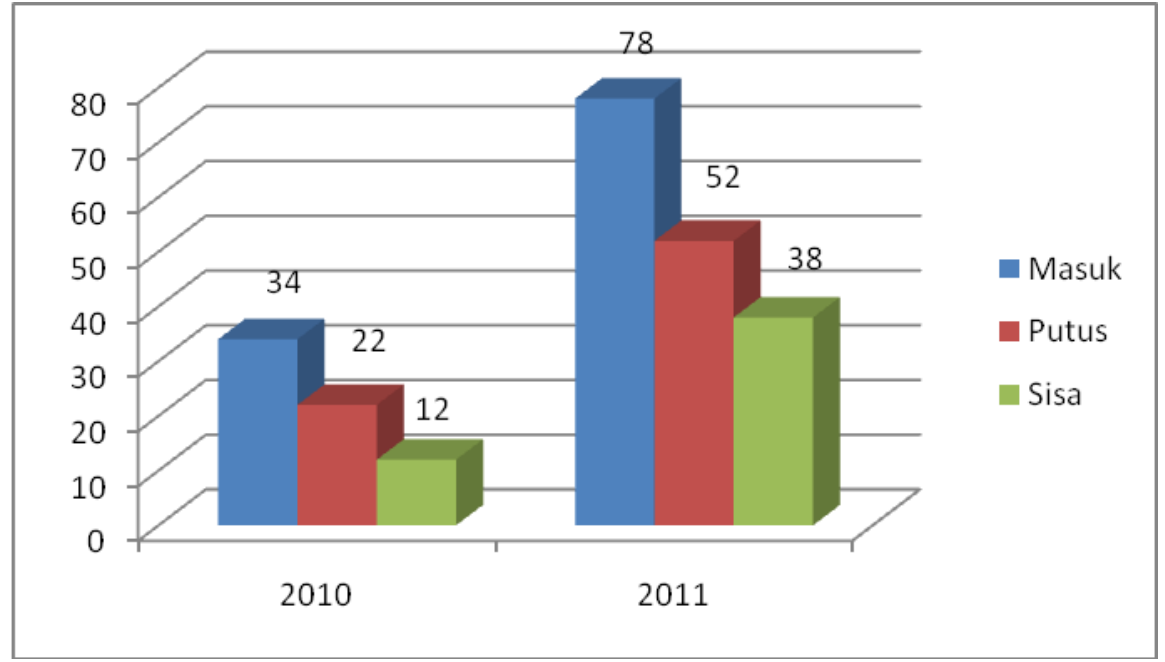

Peningkatan penanganan perkara tersebut membuat jumlah tunggakan (sisa) perkara yang belum selesai diputus bertambah 300 $\%$ (3 kali lipat) dari sebelumnya 12 menjadi 38. Namun jumlah

${ }^{80}$ Laporan Tahunan Pengadilan Negeri/Niaga/HAM/Tipkor Dan Hubungan Industrial Jakarta Pusat Tahun 2011, hal. 21. 
tersebut lebih sedikit jika dibandingkan dengan Pengadilan Tipikor Bandung (106 perkara yang disidangkan).

Ada 9 Hakim karir bersertifikat Tipikor yang bertugas di Pengadilan Negeri Jakarta Pusat. 2 dari 9 hakim tersebut merupakan pimpinan Pengadilan yang intensitas mengadilinya lebih rendah dibanding hakim lainnya. Pada Pengadilan Tipikor Jakarta melibatkan hakim bersertifikasi Tipikor pada Pengadilan Negri lainnya. Tercatat ada 3 orang yang masing-masing berasal dari PN Jakarta Timur, PN Jakarta Utara, dan Jakarta Barat. Sedangkan Hakim Ad Hoc yang bertugas ada 8 orang.

Hakim di Pengadilan Negeri lain yang diperbantukan pada Pengadilan Tipikor Jakarta tetap menyidangkan perkara umum di Pengadilan asal. Berdasarkan wawancara dengan Djoko Sarwoko, hakim tersebut hanya dibebastugaskan selama 1 hari untuk fokus mengadili perkara Tipikor di Pengadilan Tipikor Jakarta. Selain hari yang sudah ditentukan, bersidang di Pengadilan Negeri tempat asal hakim tersebut bertugas. Oleh karena hanya diberi waktu 1 hari, seringkali persidangan yang hingga malam.

Berdasarkan jumlah perkara yang masuk memang tidak sebesar Pengadilan Tipikor Bandung, akan tetapi beban kerja 1 orang hakim Tipikor Jakarta bisa melebihi. Perkara Tipikor di Jakarta disidang oleh 5 hakim sekaligus, berbeda dengan Pengadilan Tipikor Bandung yang hanya 3 orang hakim. Sehingga masing-masing hakim Tipikor Jakarta menangani lebih banyak perkara dibanding hakim Tipikor Bandung.

Berdasarkan hasil observasi di Pengadilan Tipikor Jakarta kemampuan hakim Tipikor Jakarta dalam bertanya saat tahap pembuktian dinilai cukup baik. Hakim, baik karir maupun Ad Hoc, dapat menggali dan bertanya tanpa bersikap memojokan dan diskriminatif. Meski ada beberapa hakim yang terpancing emosinya saat pihak yang diajukan dipersidangan tidak kooperatif. Tingginya sorotan dan perhatian pers di Pengadilan Tipikor di Jakarta menjadikan hakim yang bersidang menampilkan performa dan kinerja terbaiknya. Pers di Pengadilan Tipikor jumlahnya sangat banyak di tiap sidangnya hingga seringkali memenuhi area depan dan dalam ruang persidangan.

\section{Penutup}

\section{Kesimpulan}

Berdasarkan uraian dan analisis pada bagian sebelumnya, maka jabawan atas pertanyaan penelitian yang telah disampaikan adalah sebagai berikut: 
1) Hambatan yang akan timbul terkait dengan pembentukan pengadilan tindak pidana korupsi di daerah adalah:

a. Hambatan sumber daya manusia yang akan mengisi jabatan hakim ad hoc. Apabila seluruh pengadilan tindak pidana korupsi dibentuk di seluruh ibukota kabupaten/kota maka dibutuhkan hakim ad hoc yang sangat banyak untuk satu periode masa bakti. Pada sisi lain, tidak banyak calon yang memiliki kualifikasi yang cocok untuk menjadi hakim, terutama terkait dengan rekam jejak dan integritas personalnya.

b. Hambatan sarana dan prasarana untuk pembentukan pengadilan tindak pidana korupsi. Pengadilan tindak pidana korupsi yang telah dibentuk pada umumnya menggunakan ruang gedung pengadilan negeri yang pada akhirnya menghambat kinerja pengedilan negeri untuk menyidangkan perkara lainnya.

c. Sistem rekrutmen yang berlaku saat ini sangat sulit untuk mendapatkan calon-calon terbaik. Pada sisi lain tidak banyak calon-calon yang diperkirakan memiliki integritas dan pemahaman keilmuan yang memadai mendaftarkan diri untuk menjadi hakim ad hoc. Bagi hakim karir yang bertugas di pengadilan tindak pidana korupsi hingga saat ini belum memiliki standar yang memadai untuk menjadi hakim pengadilan tindak pidana korupsi. Pada sisi lain, pengadilan di tingkat pertama mengalami kekurangan hakim karir untuk melaksanakan tugas rutin pengadilan. Melibatkan anggota masyarakat untuk ikutserta dalam proses seleksi merupakan salah satu cara untuk menjamin adanya akuntabilitas dalam proses seleksi, namun hal itu bukan satu-satunya cara dan menjadi jaminan proses tersebut akuntabel. Melibatkan kalangan civil society untuk melakukan proses rekam jejak merupakan langkah yang baik, namun hal itu juga tidak selamanya dapat menghasilkan calon-calon dengan rekam jejak yang baik.

d. Hambatan lain adalah keterbatasan negara dalam menyediakan dana yang memadai dalam proses pembentukan pengadilan tindak pidana korupsi. Oleh karena keterbatsan tersebut maka pembentukan pengadilan tindak pidana korupsi tidak dapat dilakukan secara serentak.

2) Jumlah hakim karir dan hakim ad hoc yang dibutuhkan oleh pengadilan tindak pidana korupsi untuk melaksanakan tugas fungsi dan kewenangannya pada dasarnya tidak dinyatakan secara tegas di dalam UU No. 46 Tahun 2009 tentang Pengadilan Tindak Pidana Korupsi. Ketentuan Pasal 10 ayat (1) UU No. 46 Tahun 2009 menyatakan bahwa Dalam memeriksa, mengadili, dan memutus perkara tindak pidana korupsi, Pengadilan Tindak Pidana Korupsi, pengadilan tinggi, dan Mahkamah Agung terdiri atas Hakim Karier dan Hakim ad hoc. Komposisi majelis hakim pada pengadilan tindak pidana korupsi ditentukan berdasarkan kebutuhan yang dinyatakan 
berdasarkan penetapan ketua pengadilan tindak pidana korupsi. Kondisi semacam itu sangat menyulitkan untuk menghitung kebutuhan hakim ad hoc secara nyata. Sedangkan pengadilan tindak pidana korupsi berkedudukan di ibukota kabupaten/kota di seluruh Indonesia (Pasal 3 UU No. 46 Tahun 2009). Apabila diasumsikan dalam setiap pengadilan tindak pidana korupsi membutuhkan dua majelis dengan komposisi dua orang hakim karir dan satu orang hakim adhoc, maka dibutuhkan hakim karir sebanyak-banyaknya.

\begin{tabular}{|r|c|c|c|c|c|}
\hline No & Hakim & $\begin{array}{c}\text { Pengadilan } \\
\text { tingkat pertama } \\
\text { (sama dengan } \\
\text { jumlah kota dan } \\
\text { kabupaten di } \\
\text { Indonesia) }\end{array}$ & $\begin{array}{c}\text { Pengadilan } \\
\text { tingkat banding } \\
\text { (sama dengan } \\
\text { jumlah provinsi } \\
\text { di Indonesia) }\end{array}$ & $\begin{array}{c}\text { Pengadilan } \\
\text { tingkat } \\
\text { kasasi } \\
\text { (tingkat } \\
\text { MA) }\end{array}$ & $\begin{array}{c}\text { Jumlah } \\
\text { total }\end{array}$ \\
\hline 1 & $\begin{array}{c}\text { Hakim } \\
\text { Karir }\end{array}$ & $4 \times 497(1988)$ & $4 \times 31(124)$ & - & 2112 \\
\hline 2 & $\begin{array}{c}\text { Hakim } \\
\text { Adhoc }\end{array}$ & $2 \times 497(994)$ & $2 \times 31(62)$ & $2 \times 1(2)$ & 1058 \\
\hline
\end{tabular}

Ilustrasi tersebut merupakan kebutuhan minimal dari pengadilan tindak pidana korupsi yang ada di seluruh Indonesia mulai tingkat pertama hingga tingkat kasasi di Mahkamah Agung. Jumlah tersebut hanya berlaku untuk satu periode yang berkisar lima tahun. Dengan demikian, setiap periode setidaknya dibutuhkan 1058 orang hakim adhoc dan 2112 hakim karir. Mengingat kondisi dan hambatan yang muncul dalam setiap pembentukan pengadilan tindak pidana korupsi, maka pembentukan di setiap ibukota kabupaten/kota merupakan pengaturan yang tidak realistis.

3) Putusan hakim di sejumlah pengadilan tindak pidana korupsi pasca pemberlakuan UU No. 46 tahun 2009 tentang Pengadilan Tindak Pidana Korupsi pada umumnya sudah sesuai dengan tujuan pembentukannya, yaitu melakukan pemberantasan tindak pidana korupsi. Namun sejumlah putusan tersebut seakan tidak berarti karena terdapat sejumlah putusan pengadilan yang justru membebaskan para terdakwa dari jeratan undang-undang pemberantasan korupsi. Putusan bebas tersebut pada umumnya dianulir di tingkat kasasi oleh Mahkamah Agung. Hal mana menunjukkan bahwa putusan tingkat pertama tersebut sangat rendah kualitasnya. Kondisi tersebut seakan menjadi pembenara bahwa putusan dibuat berdasarkan pesanan dari pihak terdakwa karena di kemudian hari sejumlah hakim pengadilan tindak pidana korupsi ditangkap karena tuduhan menerima suap. 


\section{Saran}

Berdasarkan uraian dan kesimpulan hasil penelitian ini, maka saran yang dapat disampaikan agar pengadilan tindak pidana korupsi dapat bekerja secara efektif antara lain sebagai berikut:

1) Persoalan dualisme penanganan perkara tindak pidana korupsi yang selama ini menjadi alasan judicial review pada dasarnya tidak demikian. Pengadilan tindak pidana korupsi sebagaimana diatur oleh UU No. 30 Tahun 2002 tentang Komisi Pemberantasan Tindak Pidana Korupsi pada dasarnya tidak mengakibatkan dualisme penanganan kasus korupsi. Pengadilan tersebut hanya memeriksa perkara secara terbatas yaitu perkara yang diajukan oleh Komisi Pemberantasan Korupsi saja. Namun apabila hal itu masih dinilai dualisme penanganan kasus korupsi maka pada masa yang akan datang pengadilan tindak pidana korupsi dapat memeriksa perkara korupsi yang diajukan oleh Komisi Pemberantasan Tindak Pidana Korupsi dan Kejaksaan dengan batasan tertentu. Batasan tersebut dapat dilihat dari sisi nilai uang yang dikorupsi atau subjek yang menjadi pelaku tindak pidana korupsi. Apabila hal tersebut dilakukan maka Indonesia tidak membutuhkan pengadilan tindak pidana korupsi yang sangat banyak, mungkin hanya dibutuhkan satu pengadilan tindak pidana korupsi saja. Kasus korupsi lain yang tidak masuk ke dalam pembatasan tersebut diperiksa oleh pengadilan umum.

2) Rekrutmen hakim ad hoc yang selama ini dilakukan oleh Mahkamah Agung sebaiknya tidak selalu mengejar kuantitas. Menitikberatkan rekrutmen hanya pada faktor kuantitas pada akhirnya akan mengabaikan penilaian lain yaitu integritas dan kualitas keilmuan para calon hakim ad hoc. Kebutuhan hakim ad hoc pada dasarnya akan sangat bergantung pada jumlah pengadilan tindak pidana korupsi.

3) Peningkatan kualitas hakim pada pengadilan tindak pidana korupsi sebaiknya dilakukan secara rutin dan disesuaikan dengan perkembangan perkara tindak pidana korupsi yang diperiksa dan diputus pengadilan. Hal ini sangat dibutuhkan mengingat tidak semua hakim dapat meningkatkan kemampuan dan keilmuannya sendiri, perlu dibantu oleh institusi yang lebih besar. Terkait dengan peningkatan kemampuan hakim ini maka Mahkamah Agung dapat bekerja sama dengan Komisi Yudisial dan Komisi Pemberantasan Tindak Pidana Korupsi.

4) Putusan pengadilan tindak pidana korupsi yang sudah berkekuatan hukum tetap sudah selayaknya dapat diakses oleh masyarakat sehingga mereka dapat menilai kualitas putusan para hakim. Pada sisi yang lain diharapkan dapat memacu para hakim untuk meningkatkan kualitas putusannya dan menghindari praktik pemerasan dan penyuapan yang berujung pada putusan yang berkualitas rendah. 


\section{Daftar Pustaka}

\section{Buku}

Gultom, Binsar M. Pandangan Kritis Seorang Hakin dalam Penegakan Hukum di Inadonesia, Jakarta: PT Gramedia Pustaka Utama, 2012.

Hol, Anthony dan Marc Loth, Reshaping Justice: Judicial Reform and Adjudication in The Netherlands, dalam Luhut M.P. Pangaribuan, Lay Judges \& Hakim Ad hoc (Suatu Studi Teoritis Mengenai Sistem Peradilan Pidana Indonesia), Jakarta: FHUI \& Papas Sinar Sinanti, 2009.

KHN, Penelitian Hakim Ad hoc dalam Pengadilan Niaga, tidak diterbitkan, Jakarta 20 Januari 2005: 9.

Laporan Tahunan Pengadilan Negeri/Niaga/HAM/Tipikor Dan Hubungan Industrial, Jakarta Pusat Tahun 2011.UNODC, MA RI dan BPHN, Judicial Integrity, Tahun 2004.

Mahkamah Agung RI, Laporan Tahunan 2010, Jakarta: MA RI, 2011.

, Laporan Tahunan 2011, Jakarta: MA RI, 2012.

\section{Peraturan}

Indonesia, Undang Undang Pengadilan Tindak Pidana Korupsi, UU No. 46 Tahun 2009, LN No. 155 Tahun 2009, TLN No. 5074.

Undang-Undang No 30 tahun 2002 tentang Komisi Pemberantasan Tindak Pidana Korupsi.

Indonesia, Undang Undang Kekuasaan Kehakiman, UU No. 48 Tahun 2009, LN No. 157 Tahun 2009, TLN No. 5076.

Mahkamah Agung, Peraturan Mahkamah Agung tentang Pedoman Penyelenggaraan Seleksi Calon Hakim Ad hoc Pada Pengadilan Tindak Pidana Korupsi, Pengadilan Tinggi, dan Mahkamah Agung, Perma No. 4 tahun 2009.

\section{Putusan}

Mahkamah Konstitusi, Putusan Mahkamah Konstitusi No. 012-016-019/PUUIV/2006.

\section{Internet, Surat Kabar dan Majalah}

"Bubarkan Pengadilan Tipikor Daerah, Pilihan Politik Hukum", <http://nasional.kompas.com/read/2011/11/04/22330494/Bubarkan.Peng adilan.Tipikor.Daerah.Pilihan.Politik.Hukum>, diakses 5 Maret 2012. 
"Hasil Kajian ICW tentang Putusan Bebas Terhadap Terdakwa Korupsi di Pengadilan Umum", <www.antikorupsi.org>

"Jimly: Pengadilan Tipikor Daerah Tak Perlu Dibubarkan", $<$ http://nasional.kompas.com/read/2011/11/05/12553580/Jimly.Pengadila n.Tipikor.Daerah.Tak.Perlu.Dibubarkan>, diakses 16 Juli 2012.

"Kembalikan Pengadilan Tipikor ke PN", <http://www.riauupdate.com/ nasional/item/171-kembalikan-pengadilan-tipikor-ke-pn.html?tmpl= component\&print=1>, diakses 5 Maret 2012.

"KY: Bekukan Tipikor Daerah Sementara", <http://pekanbaru.tribunnews.com/2011/11/09/ky-bekukan-tipikordaerah-sementara>, diakses 5 maret 2012.

"KY Dukung Pemusatan Pengadilan Tipikor Daerah", $<$ www.hukumonline.com/berita/baca/lt4eb7c260e07ca/ky-dukungpemusatan-pengadilan-tipikor>, diakses 5 Maret 2012.

"Pengadilan Tipikor Daerah Vonis Bebas 50 Koruptor, <http://news.okezone.com/read/2012/03/04/339/586884/pengadilantipikor-daerah-vonis-bebas-50-koruptor>, diakses 16 Juli 2012.

"Pengadilan Tipikor Dikembalikan Ke Pusat", <http://suararakyat.net/ index.php?option=com_content $\&$ view=article $\& i d=191$ :pengadilantipikor-dikembalikan-ke-pusat\&catid $=141 \&$ Itemid $=577>$, diakses 5 Maret 2012.

<http://www.republika.co.id/berita/nasional/umum/12/03/20/m16bgo-dprberharap-putusan-ma-bukan-pencitraan>, diakses 11 September 2012.

<http://www.seputar-indonesia.com/edisicetak/content/view/522455/>, diakses 11 September 2012.

<http://www.hukumonline.com/berita/baca/lt4dfde434e4dd6/pemerintahtegaskan-hakim-iad-hoci-bukan-pejabat>, diakses 28 Agustus 2012.

$<$ http://news.okezone.com/read/2011/11/14/339/529371/ma-tatar-hakim-adhoc-tipikor>, diakses 24 Juli 2012.

<http://www.judcom.nsw.gov.au/>, diakses 28 Agustus 2012.

<http://www.judcom.nsw.gov.au/education/education>, diakses 28 Agustus 2012.

Kompas, “Benteng Terakhir Semakin Lapuk”, 14 November 2011.

Kompas, “MA Tambah 4 Pengadilan Tipikor”, Rabu 13 Juni 2012.

Majalah Tempo, edisi 16-22 September 2012.

Majalah Tempo, edisi 10-16 September 2012. 


\section{Jurnal}

Reza Fikri Febriansyah, "Mengadili Eksistensi Pengadilan Tindak Pidana Korupsi”, dalam Teropong, Depok: MaPPI FHUI, 2007: 41.

\section{Paper}

Desita Sari dalam Focus Group Discussion: Evaluasi Kinerja Pengadilan Tindak Pidana Korupsi, diselenggarakan oleh MaPPI FHUI di Hotel Morissey, Jakarta, 31 Agustus 2012.

Focus Group Discussion: Evaluasi Kinerja Pengadilan Tindak Pidana Korupsi, diselenggarakan oleh MaPPI FHUI di Hotel Morissey, Jakarta, 31 Agustus 2012.

Narendra Jatna dalam Focus Group Discussion: Evaluasi Kinerja Pengadilan Tindak Pidana Korupsi, diselenggarakan oleh MaPPI FHUI di Hotel Morissey, Jakarta, 31 Agustus 2012. 